\title{
Assessing the Dynamic Tourism Inter-Industry Linkages and Economic Structural Changes in Cambodia's Economy
}

Chantha - Hor ( $\sim$ hor.chantha@a.mbox.nagoya-u.ac.jp )

Nagoya University

Research

Keywords: Tourism inter-industry linkage, structural changes, SAM-based input-output model, Multiplier Production Matrix Model, fields of influence

Posted Date: March 4th, 2020

DOI: https://doi.org/10.21203/rs.3.rs-16067/v1

License: (c) (i) This work is licensed under a Creative Commons Attribution 4.0 International License.

Read Full License

Version of Record: A version of this preprint was published at Journal of Economic Structures on September 15th, 2021. See the published version at https://doi.org/10.1186/s40008-021-00249-1. 


\title{
Assessing the Dynamic Tourism Inter-Industry Linkages and Economic Structural Changes in Cambodia's Economy
}

\author{
Mr. Chantha Hor \\ Graduate School of International Development, Nagoya University \\ E-mail: hor.chantha@a.mbox.nagoya-u.ac.th \\ Furo-Cho, Chikusa-Ku, Nagoya 464-8601, Japan
}

\begin{abstract}
This study employs the SAM-based model combining with Multiplier Production Matrix and Field of Influence Approach. Under three Input-Output Transaction Table Matrices of the year 2005, 2010, and 2015, these approaches use to assess the dynamic tourism inter-industry linkages and structural economic changes in Cambodia. We find that the overall interindustry connection is relatively low. The textile, other manufacturing, and transportation and communication are key sectors. They have the largest coefficient field of influence of changes in the economic system. Tourism has shifted to be a key sector in 2010 and 2015. However, its backward and forward linkages are still small. It is a relatively promising sector in terms of generating a large coefficient field of influence of changes, showing less strength of overall connection with other industries. This study may suggest that there would be a need for promoting, encouraging, and investing in key economic sectors. Policies intervention should focus on developing domestic tourism linkages and strengthening interindustry ties for the success of diversifying tourism benefits to the local economy.
\end{abstract}

Keywords: Tourism inter-industry linkage, structural changes, SAM-based input-output model, Multiplier Production Matrix Model, fields of influence

JEL Classification: L16, R15, Z32 


\section{Introduction}

Tourism has endorsed an economic powerhouse contributing to economic development. Globally, it shared $10 \%$ of gross domestic product (GDP), $29 \%$ of service exports, and created a job in every ten jobs in 2018 (UNWTO, 2018).

Interestingly, it has primarily recognized as a leading economic facilitator in either developed or developing countries. In 2018, the travel and tourism industry internationally ranked the second-swiftest flourishing sector. It accounts 3.9\% annual average growth rate, marginally behind the manufacturing industry (4\%) (WTTC, 2019). The ongoing expansion of tourism development has brought many researchers to identify its role in the economic system. Moreover, many governments in developing countries place the tourism sector into their country's priority economic development plan. However, it does not appear precisely as a distinctive industry either in the national account or the input-output table (IOT). Because it characteristically constitutes a set of various goods and services (Banerjee et al. 2016; Lejarraja and Walkenhorst 2007). This nature of tourism makes complexity and challenges in measuring its economic performance. Various ways have used to investigate the tourism economic impact on industrial activities in the context of rich and poor data availability. Some scholars investigate the tourism economic impact by summing the International Standard Industrial Classification (ISIC) Division 55 and 60-63 ${ }^{1}$ representing the tourism sector (Slob and Wilde 2006).

\footnotetext{
${ }^{1}$ ISIC Division of 55, 60, 61, 62, and 63 represent of hotel \&restaurant, land, water, air transport, and supporting transport activities, respectively.
} 
Some researchers define the tourism industry by using the closet tourism-related characteristic or tourism-related industry (see Kweka et al. 2003; Kronenberg et al. 2018; Pratt 2011; Ferrari et al. 2018; Pambudi et al. 2009; Chaivichayachat 2017). Several papers have integrated the TSA into the framework of the IOT to examine the tourism economic impact (Madsen and Zhang 2010; Jones and Munday 2010; Munjal 2013; Smeral 2015; Antara and Sumarniasih 2017). Cambodia has seen a limitation of tourism data compare to its neighboring countries. In this context, this study adopts the method suggested by Slob and Wilde (2006) to define the tourism sector in the IOT. Conspicuously, tourism has articulated with many industries in the IOT, which records the business transaction of all economic activities in the economy (Zha et al. 2019). It generates economic benefits via the intra-and inter-sectorial links between the tourism-related and other industrial segments (Grosso et al. 2007).

In past studies, scholars have applied several economic impact tools ${ }^{2}$ to understand the tourism economic impact and its linkages at different levels (local, national, regional, and global) (see Archer and Fletcher 1996; Dwyer et al. 2003; Kweka et al. 2003; Pambudi et al. 2009; Pratt 2011; Khanal et al. 2014; Robles et al. 2014; Antara and Sumarniasih 2017; Chaivichayachat 2017; Kronenberg et al. 2018; Ferrari et al. 2018; Zha et al. 2019). Notably, Yousif and Al Bakr (2017) employ the IO method to estimate the tourism economic effects on the Saudi Arabian economy. Pratt (2015) used various models (i.e., IO, Backward-andforward, and CGE) to investigate the impact of the tourism industry on the Small Island

\footnotetext{
${ }^{2}$ Input-output (IO) model, social accounting matrix (SAM) model, computable general equilibrium (CGE), Tourism satellite account (TSA) model
} 
Developing States (SID). Carrascal and Fernández (2015) adopted the SAM approach to calculate the economic effects of the tourism industry on regional economic development in Spain. Banerjee et al. (2016) explore the influence of the tourism industry in the context of limited data by employing the CGE approach. Antara and Sumarniasih (2018) applied the TSA method for measuring the tourism industry's role in Bali's and Indonesia's economy. Although there are likely abundant studies in tourism economic impact, there has remained a lack of studies using multiple periods of IOT in developing countries. Furthermore, there have also been inadequate tools to explain the tourism industry's linkage pattern in developing countries.

This paper, to fill the shortage, provides empirical research for the case of Cambodia. Cambodia is a less developed country in Southeast Asia, which borders to the northwest with Thailand, to the north with Laos PDR, and to the east with Vietnam. Cambodia's economy has approximately grown by about 7.7\% from 1995 to 2018, annually (ADB 2019). The government accounted for the tourism sector as an essential economic activity and gave equal weight to the agriculture and manufacturing industry (Kaynak and Kara 2012). Importantly, it has integrated into the top country's priority strategic development plan for achieving economic development and poverty alleviation (ROG 2018). Nevertheless, most studies have overlooked this industry. Meanwhile, many papers have focused on the garment and textile industry (Salinger et al. 2005; Yamagata 2006; Asuyama and Neou 2012), the agriculture and fishery (Kobayashi et al. 2009), and agriculture and agro-agriculture industry (Chhuor 2017). 
To this end, this paper structures to assess the dynamic tourism inter-industry linkages and economic structural changes in Cambodia's economy. We use three years of the IOT (2005, 2010, and 2015). This study's objective is to address two central questions: How does the economic structural change evolve in a nationwide economy? How does the tourism industry importance in the Cambodian economy in terms of linkages? This research makes three contributions. First, it enriches discussion on how to integrate government policy intervention to adjust domestic production to satisfy the future tourism demand. Second, it enhances debates about the evolution of tourism linkage's pattern in the economy. Third, it is the first study to perform the Fields of Influence approach for an in-depth illustration of how the tourism industry interconnects with other sectors.

This study designs into seven sections. Section two and three outline tourism development in Cambodia and relevant previous studies, respectively. Then, sections four and five describe the research method and data source. Section six interprets the result and discussion, and finally, section seven is the conclusion.

\section{Tourism Development in Cambodia}

Cambodia's tourism sector has reinstated playing a predominant role in the economy in 1992 after a period of disappearance. This absence was because of the civil war, armed conflicts, and political instabilities in the 1970s and 1980s (Chheang 2008). Cambodia has many excellent tourism endowments, such as archeological heritage, historical, cultural, and natural resources (ADB 2009). These tourism assets located in various geographical areas of the country. These assets are the potential to attract millions of tourists to visit Cambodia (Kaynak and Kara, 2012). In the current decade, an increasing number of international 
tourism arrivals in Cambodia registered over time, except in 1997, 2003, and 2009. This exception period of interrupting tourists' inflow hit by the Asian financial crisis, global financial crisis, and other adverse shocks (i.e., SARS epidemics and political instability) (Hor and Thaiprasert 2014; Chhorn 2017). The tourist arrivals in Cambodia have surprisingly soared from 60,000 in 1991 to 6.2 million in 2018 (as seen in Figure 1). Similarly, the foreign tourism receipts remarkably raised from 100 million USD in 1995 to 4.4 billion USD in 2018 (MOT 2019). Comparing with other ASEAN countries, Cambodia has achieved the highest growth share of tourism GDP (2000-2018), tourism employment (2004-2018), and tourism visitor's export (2005-2018) (WTTC 2019).

Perhaps, because of its continued growth and expansion, the Cambodian government has integrated the tourism sector into the top national development plan for "growth, employment, equity, efficiency, and poverty alleviation" (ROG 2018). It appeared in the fiveyear national socio-economic development plan (NSEDP) (1995-2000), national strategic development plan (NSDP) (2001-2005, 2006-2010, \& 20014-2018). In these plans, the government has identified various barriers to tourism development (i.e., high cost of the package tour, inadequate physical infrastructure, low tourism service quality, shortage of human resource quality, lack of tourism products, and external negative shocks). The plan has proposed various action plans, i.e., improve physical infrastructures, open sky policy, diversify tourism products and services, visa facilitation, tourism promotion campaign, and develop tourism products at priority tourism areas (Northwest Zone, Central Zone, Coastal Zone, and Eco-tourism Zone). Besides, the government issued tourism law, and strategic 
development plans ${ }^{3}$ to develop, promote, diversify tourism destinations and enhance local economic benefits. Undeniably, the tourism sector has been considered by the government to boost Cambodian economic development. However, as reported by the Cambodian Ministry of Tourism, the tourism sector relatively small contributes to the domestic economy due to the considerable size of economic leakage.

Figure 1: International Tourism Development in Cambodia, 1991-2018

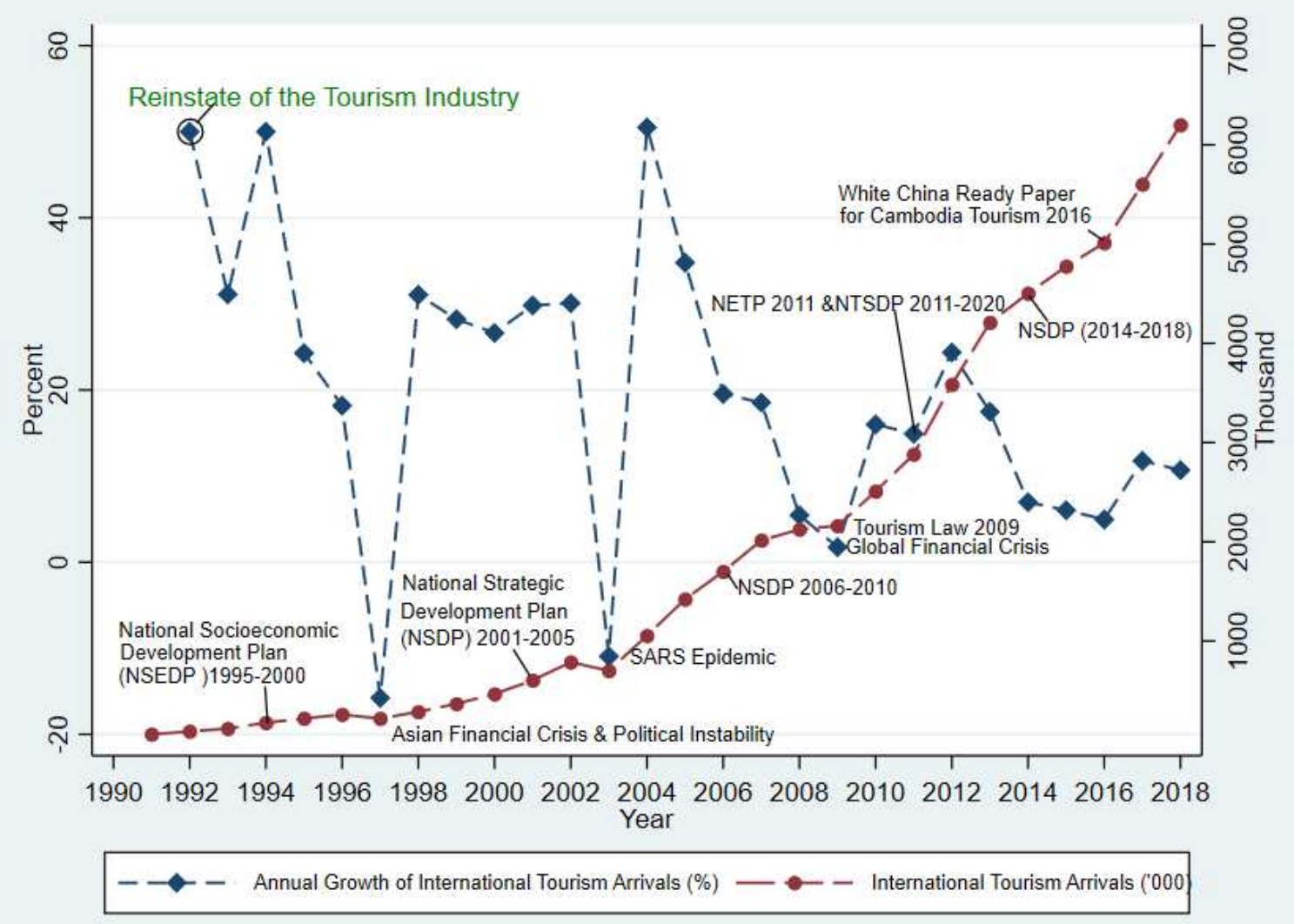

Note: National ecotourism development policy (NETP), National tourism strategic development plan (NTSDP)

Source: Author's elaboration based on many sources

\section{Literature Review}

${ }^{3}$ Tourism law in 2009, national tourism strategic development plan (NTSDP) (2011-2020), national ecotourism development plan (NETDP) in 2011, and White China ready paper for Cambodia's tourism in 2016 
The linkage analysis is predominant in understanding the inter-industry association between sectors in the economy. It equips a few essential advantages. First, it gives an overall picture of economic structure and how domestic production has changed overtimes. Second, it accommodates information for the sector's classification or industry's position in the economy. Third, it shows the strength of linkages among industries (Pratt et al. 2018; Gabriel and Ribeiro 2019). There are two types of economic ties, i.e., backward linkage (BL) and forward linkage (FL) (Cai et al. 2006). The BL reveals demand relation between sectors. For example, if the industry (A) enlarges producing its products, there is then bourgeoned demand on other industries whose outputs utilize as raw materials in the sector (A). Whereas, the FL marks the supply association. That is, an increase in producing products in the industry (B) is the additional volume in production at sector (B) that is available to be used as raw materials/intermediate goods for another industry's output.

The linkage tools, over the last six decades, have been adopted for use in economic development in terms of conveying the interdependence and inter-sectoral linkages between industries. Evolutionally, the linkage methods were firstly introduced by Rasmussen (1956), Hirschman (1958), and Chenery and Watanabe (1958). Later, there have extensively developed and broadly discussed (see Schultz 1977; Celia 1984; Sonis et al. 1997; Miller and Blair 2009; Temurshoev 2010).

Plethora studies use various econometric tools to investigate the tourism economic impact and its linkages in different countries. Previous studies have done for the case of Laos PDR (Khanal et al. 2014), Malaysia (Mazumder et al. 1993), China (Oosterhaven and Fan 2006), India (Munjal 2013), Indonesia (Antara and Sumarniasih 2017), Thailand (Vora-Sittha 
2016), Turkey (Akkemik 2012), Central Finland (Tohmo 2018), Ireland (Henry and Deane 1997), South Korea (Kim and Kim 2015), and Israel (Freeman and Sultan 1997). Henry and Deane (1997) use the IO approach to calculate the effects of tourism expenditure and passenger fares on Ireland's economy between the years 1990 and 1995. The study finds that the tourism sector contributes to Ireland's output between 7 to 11 percent. Atan and Arslanturk (2012) exert the IO model to study tourism and economic growth nexus, including exploring tourism economic linkages in Turkey. The finding shows that tourism is not a vital sector in Turkey. Furthermore, all tourism-related industries have a high value of backward linkages.

Yousif and Al Bakr (2017) utilize the IO approach to evaluate the role of tourism on the Saudi Arabian economic diversification. Their finding indicated that tourism is a positive direct-and-indirect impact on the Saudi Arabian economy. The scholars suggest increasing budgets on the tourism industry to diversify the country's economy to achieve the country's vision 2030. Khanal et al. (2014) use a series of linkage methods to evaluate the inter-industry linkage between Laos PDR tourism sector and other industries based on the IOT 2003-2008. The study found that the Laos PDR tourism industry contributes positively to the level of dependency in the economy during 2003-2008. Manufacturing, agriculture, wholesale and retail, food and beverage, and tourism sector are the dominant sector over the studied periods. The enlargement of the tourism industry stimulates and enables the country to be one of the highest economic growth in the Great Mekong sub-region countries. Chaivichayachat (2017) examines the inter-sectorial linkage between related-tourism sectors in Thailand by separating three main periods, such as in the past (1975-2013), in the present (2014-2016) 
and the future (2017-2027). He finds the tourism-related industry is backward-oriented in the past, and move to the forward-oriented sector in the present and future periods. The fastgrowing pace of tourism sector starts more significant linkages on the country's economy than in the past. His study also suggests numerous policies to promote tourism and to enhance the Thai economy.

Akkemik (2012) explored the SAM approach to estimate the economic contribution of the tourism industry on Turkey's economy. The result shows that tourism GDP elasticity is relatively small. The tourism expenditures are a medium impact on production, value-added, and employment. The study also emphasized that there was a high probability of foreign economic leakages in the Turkish economy. A similar study was done by Muchapondwa and Stage (2013) for the case of South African, Motswana, and Namibian economy. The outcome demonstrates the overall economic impact of tourism on South African GDP, about 6 percent, and 9 percent for Namibia. The study pinpoints that the economic leakage in South Africa is smaller than its neighboring countries. Although there are likely abundant tourism studies exploring tourism linkages and their economic impact, little studies concern the dynamic and evolution linkage pattern of the tourism industry. Furthermore, those studies have overlooked the direct change coefficient of inter-industry with the other sectors using the field of influence approach.

\section{Research Method}

The SAM-based Input-output model uses in this study, followed by Defourney and Thorbecke (1984) and Otchia (2013):

$$
\mathrm{Y}=(\mathrm{I}-\mathrm{A})^{-1} \mathrm{X}=\mathrm{BX}
$$


$\mathrm{Y}$ and $\mathrm{X}$ are the receipts from income and expenditure accounts, respectively. The income account composes activities, commodities, households, and factors of production account, while capital, government, and the rest of the economy are assigned to be expenditure accounts.

This study uses the minimum information method proposed by Sonis et al. (1997) to decompose matrix of Leontief inverse (MLI) into two-part, namely the MPM and the Matrix Synergetic Interaction (MSI). Therefore, the minimum information depended on the decompose MLI, which can express as:

$$
\begin{gathered}
\mathrm{B}=\mathrm{T}_{1}-\mathrm{T}_{2} \\
-\mathrm{T}_{2}=\mathrm{D}+\mathrm{S}+\mathrm{S}_{\mathrm{a}}
\end{gathered}
$$

Where $\mathrm{T}_{1}$ and $\mathrm{T}_{2}$ are the MPM and the matrix of MSI, respectively. $\mathrm{D}$ refers to the additional sectorial scale effects. $S$ and $S_{a}$ are the symmetric and anti-symmetric tendencies in the synergetic cooperation between industries.

\subsection{Key Sector Analysis}

Following Sonis et al. (1997), the MPM approach set as below:

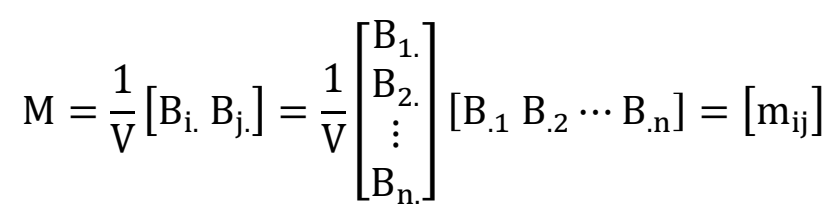

Where, $\mathrm{V}=\sum_{\mathrm{i}=1}^{\mathrm{n}} \sum_{\mathrm{j}=1}^{\mathrm{n}} \mathrm{b}_{\mathrm{ij}}$ is a summation of all cells in the inverse matrix, $\mathrm{B}_{\mathrm{i} .}=\sum_{\mathrm{i}=}^{\mathrm{n}} \mathrm{b}_{\mathrm{ij}}$ and $\mathrm{B}_{\mathrm{j}}=\sum_{\mathrm{i}=}^{\mathrm{n}} \mathrm{b}_{\mathrm{ij}}$ is the summation of total ith row and jth column of MLI.

The linkage analysis proposed by Rasmussen (1956) equated as followed: 


$$
\begin{aligned}
& \mathrm{BL}_{\mathrm{j}}=\frac{\frac{1}{\mathrm{n}} \sum_{\mathrm{i}=1}^{\mathrm{n}} \mathrm{b}_{\mathrm{ij}}}{\frac{1}{\mathrm{n}^{2}} \sum_{\mathrm{i} . \mathrm{j}=1}^{\mathrm{n}} \mathrm{b}_{\mathrm{ij}}}=\frac{\frac{1}{\mathrm{n}} \mathrm{B}_{. j}}{\frac{1}{\mathrm{n}^{2}} \mathrm{~V}}=\frac{\mathrm{B}_{. j}}{\frac{1}{\mathrm{n}} \mathrm{V}} ; \\
& F L_{i}=\frac{\frac{1}{n} \sum_{j=1}^{n} b_{i j}}{\frac{1}{n^{2}} \sum_{i . j=1}^{n} b_{i j}}=\frac{\frac{1}{n} B_{i}}{\frac{1}{n^{2}} V}=\frac{B_{i}}{\frac{1}{n} V}
\end{aligned}
$$

Where $\mathrm{FL}_{\mathrm{i}}$ and $\mathrm{BL}_{\mathrm{j}}$ represent the index of forward and backward, respectively. We conclude four types of industries. (i) key sectors (both linkages measure larger than 1); (ii) backwardoriented sectors (only, $\mathrm{BL}_{\mathrm{j}}>1$ ); (iii) forward-oriented sectors (only, $\mathrm{FL}_{\mathrm{i}}>1$ ); and (vi) weak sectors (both linkages measure smaller than 1).

In addition to the linkage analysis, we can establish the structural landscape of the economy by reorganizing the structure of MPM (Otchia, 2013). The summation of the $\mathrm{i}$-th row and jth column of the MPM is restructured based on the rank-size hierarchy of the FL and BL. The components of the MPM in this hierarchical system show the strength of the first order of field of influence of changes. These strengths utilized to estimate crucial inverse parameters for which changes create the most extensive effects in the IO system (Otchia, 2013).

$$
\mathrm{M}=\mathrm{T}_{1}
$$

\subsection{Matrix of Impacts of Synergetic Interactions (MISI)}

The MISI expresses as equation (8) for interpreting the changes of two components of the direct input matrix. Then, the MISI has broken down into escalating impacts of the interindustry production activities (D) and linkages (R) as below:

$$
\begin{gathered}
\mathrm{T}_{2}=\mathrm{M}-\mathrm{B} \\
\mathrm{R}=-\mathrm{D}-\mathrm{T}_{2}
\end{gathered}
$$


Where $\mathrm{D}$ and $\mathrm{R}$ are the matrix of diagonal $\mathrm{T}_{2}$ and residual with a zero main diagonal. The last decomposition of the MISI is R has to divide into two elements, such as symmetric (S) and anti-symmetric $\left(\mathrm{S}_{\mathrm{a}}\right)$. According to Otchia (2013), these two components show the respective balance and unequal between industrial inputs and outputs. We can express it as equation (10)

$$
\mathrm{R}=\frac{1}{2}\left(\mathrm{R}+\mathrm{R}^{\prime}\right)+\frac{1}{2}\left(\mathrm{R}-\mathrm{R}^{\prime}\right)=\mathrm{S}+\mathrm{S}_{\mathrm{a}}
$$

Where $\mathrm{R}^{\prime}$ is the transposed matrix.

\subsection{Direction of Change in the Leontief Inverse}

The Field of influence approach uses to evaluate the direction of change in the matrix of Leontief inverse. It helps to measure the changes of direct input coefficients and their linkage impacts on the component in the MLI. The changes in the linear input coefficient can express as the following equation:

$$
\Delta \mathrm{a}_{\mathrm{ij}}=\mathrm{a}_{\mathrm{ij}}(\mathrm{t}+1)-\mathrm{a}_{\mathrm{ij}}(\mathrm{t})
$$

Where $\Delta \mathrm{a}_{\mathrm{ij}}$ is the change of linear input coefficient at period $\mathrm{t}$ and $\mathrm{t}+1 ; \mathrm{a}_{\mathrm{ij}}(\mathrm{t})$ is the coefficient of direct input at time $t$.

We control the changes of direct input coefficient at time $t$ and $t+1$; parameter $0 \leq \varepsilon \leq 1$ introduces as the following equation.

$$
\mathrm{a}_{\mathrm{ij}}(\varepsilon)=\mathrm{a}_{\mathrm{ij}}(\mathrm{t})+\varepsilon \Delta \mathrm{a}_{\mathrm{ij}}
$$

The matrix $A(\varepsilon)=\left[a_{i j}(\varepsilon)\right]$ and its corresponding Leontief inverse $\mathrm{M}(\varepsilon)=\left[\mathrm{a}_{\mathrm{ij}}(\varepsilon)\right]^{-1}$ are considered as follows. 
- The $\varepsilon=0, \mathrm{~A}(0)$ presents the technical coefficient matrix at period $\mathrm{t}$ with the Leontief inverse, $\mathrm{A}(0)^{-1}$;

- The $\varepsilon=0, \mathrm{~A}(1)$ marks the technical coefficient matrix at time $\mathrm{t}+1$ with the inverse Leontief, $\mathrm{A}(1)^{-1}$;

- For the small values of $\varepsilon$, the expression $H(t+1, t)=\frac{[M(\varepsilon)-M(0)]}{\varepsilon}$ is nearly constant, and the number of directions of changes in the Leontief inverse from period ( $t$ ) and $(\mathrm{t}+1)$.

\section{Data}

Cambodian IOT has developed and released by the researcher and international institutions.

Dr. OUM Sothea established the first IOT. His two years of IOT (2004 \& 2008) have officially published in the Global Trade Analysis Project (GTAP) database. It composes of $35 * 35$ sectors for the year 2004 and $22 * 22$ industries for the year 2008 . The second source is the 60x60 Supply and Use Table 2011, developed by ADB (2012). The third source of IOTs has established by the Organization for Economic Co-operation and Development (OECD). It contains $35 * 35$ sectors covering from 1995 to 2015 . The OECD constructs the Cambodian IOT, which adopts the industry * industry approach. Hence, this table is a handful of structural and linkage analysis because it covers all industries in the economy.

As mention above, this study investigates the dynamic tourism inter-industry linkages and structural economic changes in Cambodia. We choose IOT that obtain from the OECD statistical database (https://stats.oecd.org/Index.aspx?DataSetCode=IOTSI4_2018) because it covers a more extended period than other sources. Three years of IOT $(2005,2010, \& 2015)$ 
have used in this study. Each original 35 -sector IOT is aggregated into 15-sector as Table.1 in the appendix.

\section{Result and Discussion}

\subsection{The Summary Statistics of Cambodian Industrial Structure, 2005-2015}

This section describes the industrial structure base on IOTs of the year 2005, 2010, and 2015, as presented in Table.2. Cambodia's economy depended on the agriculture sector, which accounted for $30 \%$ of total gross output in 2005 and then fell to $29 \%$ in 2015 . It was the highest contributor to overall GDP and value-added but relatively lost its share to the manufacturing and service sectors. During 2005-2015, five economic segments (namely, food and beverage, transportation and communication, textile, other manufacturing, and tourism sector) were the dominant sector contributing to the total gross output and GDP. These sectors were also the top ranking in terms of providing a significant share to valueadded. Meanwhile, all sub-service sectors' stock to gross output and GDP, except tourism, have soared over observed periods. Oppositely, these sectors were nearly constant growth contributing to value-added.

The export and import structure of Cambodia has displayed in table 3. Cambodia mainly exports agricultural, textile, other manufacturing, and construction items. These four categories accounted for $84 \%$ of total exports in 2005 and then decreased to $79 \%$ in 2015 . This trend was in favor of the service sector, which made up 9.7\% in 2005, and 14\% in 2015. The tourism sector represented the second-largest share to total exports in the service sector after the wholesale and retail industry. The sector's export intensity defines as the ratio of each sector's export to domestic production. In 2005, the textile industry was the most exportintense industry, which exported $59 \%$ of its outputs to foreign markets. It followed by 
agriculture (46\%), other manufacturing (41\%), and the food and beverage industry $(25 \%)$. In 2010, the textile, other manufacturing, and construction industry showed the top three most export-intense sectors, approximately $49 \%, 43 \%$, and $38 \%$, respectively. These industries were ahead of the food and beverage (21\%) and the tourism industry (20\%). In 2015, the construction sector was the second most export-intense, followed by the other manufacturing (37\%), mining (31\%), agricultural (24\%), and tourism industry $(21 \%)$. The export intensity of the tourism sector has surged from $14 \%$ in 2005 to $21 \%$ in 2015 . This increasing trend pinpoints that Cambodia's tourism industry highly depends on the growth of international tourist demand. It is also the main service export, which possibly generates a considerable amount of export-earning.

Regarding imports, Cambodia highly imports other manufacturing, textile, wholesale and retail, and construction items, which exhibit $92 \%$ of total imports in 2005 before decreasing to $85 \%$ in 2015 . The share of tourism import to total import has surged from $0.8 \%$ in 2005 to $5 \%$ in 2015 . Moreover, table 3 shows the import intensity of each sector, which identifies as the proportion of imports to domestic production. The other manufacturing sector found the most import-intense in 2005 , which imported $124 \%$ of its output. This figure indicates that local supply in this sector far below the level to cover self-sufficiency. At the same period, other industries that face high import penetration were textile $(78 \%)$, electricity $(67 \%)$, wholesale and retail (56\%), construction (53\%), mining and quarrying (37\%), and financial and insurance (31\%). In 2010, other manufacturing and textile industries remained the most import-intense sector concerning $77 \%$ and $70 \%$, but lower than the previous year. It was followed by electricity, mining and quarrying, wholesale and retail, and financial and 
insurance, with $57 \%, 46 \%, 45 \%, 38 \%, 20 \%$, respectively. In 2015 , the construction ( $87 \%$ ), other manufacturing (72\%), electricity (63\%), mining and quarrying $(61 \%)$, and textile industry (58\%) appeared the most import-intense.

Table 4 provides the structure of labor income and its intensity. The agriculture and other manufacturing industry were the highest contributions to total labor income for all three years but a relatively downward trend. The textile industry was the third-largest labor income contribution in 2005, ahead of the tourism, transportation and communication, and wholesale and retail industry. Between 2010 and 2015, the top three service sectors (i.e., tourism, wholesale and retail, and transportation and communication) showed a significant contributor to total labor income. These sectors imply the importance of service industries concerning contribution to net value-added. The labor income intensity of each area also included in table 4. It is the fraction of labor income to total domestic production. Two service sectors (public administration and education) were the most labor income-intense industry for all three years. It is followed by the tourism industry, which displayed an increasing trend from $27 \%$ in 2005 to $34 \%$ in 2015 . This sector indicates that it potentially generate employment and labor income earning. The labor income intensity of the construction sector has sharply increased in 2015 from the lowest labor income intense in 2005, implying that this industry is vital for job creation.

Besides, Table 5 depicts the final demand structure of all sectors during 2005-2015. Cambodia's economy depends on private consumption, which accounts for $83 \%$ in 2005 , and $81 \%$ in 2015 . The agriculture, food and beverage, and other manufacturing sectors were the top three highest share to the total private consumption. The tourism industry ranked the top 
4 and later moved to the fifth in 2015. The investment was the second-biggest share of the economy after private expenditure consumption, with a contribution of $20 \%$ in 2005 , and $20.8 \%$ in 2018 . It followed by government expenditure consumption. Interestingly, the tourism sector was the second-largest trade surplus after the agriculture sector in 2005 and 2010 and then shifted to the third in 2015. While most industries faced the sector's trade deficit.

\subsection{Backward-and Forward Linkage Analysis}

This section illustrates, in table 6, the result of Hirschman-Rasmussen BL and FL indices during 2005-2015. The BL is also called the intensity of intermediate inputs. It indicates that a sector demands raw materials from other industries for their production. The FL shows an economic activity that supplies intermediate inputs to other sectors and final domestic demand. The sectorial tie measured by using the PyIO 2.1 software.

The analysis finds that seven out of fifteen sectors (namely, food and beverage, other manufacturing, construction, textile, transportation and communication, electricity, and tourism) have relatively had strong backward linkage in the three-point periods. These sectors point out that these industries are input dependent on other economic segments. These industries are importantly and positively impact on the nationwide economy. Diversely, the rest of the sectors have shown weak backward linkage. Most service sectors (e.g., wholesale and retail, financial and insurance, real estate, public administration, education, and human health) exhibit low backward linkage. It argues that these industries are relatively less intermediate inputs demand from other economic segments. The agricultural and mining and quarrying sector have resulted in the low backward linkage, implying that both areas are the 
relatively small degree of input dependence on other industries in the economy. The textile, other manufacturing, construction, transportation and communication, and wholesale and retail registered as the top five highest forward linkages across periods. These sectors imply an essential role in supplying inputs to other economic segments. The agriculture and tourism sectors showed a strong forward tie in 2010 and 2015. In contrast, most service sectors have low forward linkage, exhibiting that these industries are relatively small supply inputs to other economic segment activities.

Concerning the linkage trend, the tourism industry has decreased backward linkage overtime periods. This sector pinpoints that this sector is relative to demand intermediate inputs from its industry or sub-related sectors. On the contrary, the tourism sector has increased its forward linkage across times, implying that this sector supplies inputs to other economies via business travel segments. The strong tourism forward linkage may generate high backward linkage in its related industries. It is in line with the construction, wholesale and retail, and transportation and communication, showing a stable and robust growth of backward linkage. Also, the increasing trend of the forward linkage in both the transport and communication and tourism sector reflects the significant international tourism growth pattern.

\subsection{Key Sector Analysis}

The key sector analysis uses to cluster segments into four types: key industries, forwardoriented sectors, backward-oriented sectors, and weak sectors. This classification bases on normalize backward-and forward linkage indices, which clearly explain in section 4.1. The

observed economic segments have categorized into four quadrants, which show in figure 2 
to 4. The upper right-and-left quadrants are, respectively, forward-oriented and key sectors. The lower right-and-left quadrants are backward-oriented and weak sectors, respectively. We find that the textile, other manufacturing, and transportation and communication sectors are key sectors that have BL and FL higher than one. The tourism sector shifted to a key sector in 2010 and 2015. This industry means that a surging investment or productivity these sectors provide a spillover impact on other industries. The backward-oriented industries are across three years, namely, the food and beverage, electricity, and construction industry. Whereas, mining and quarrying sector became a backward-oriented sector in 2015. It indicates that an increase in these sectors' production provides a more input demand from other industries. The wholesale and retail industry is continuously a forward-oriented sector across periods. The agriculture placed into the forward-oriented economic segment in 2010 and 2015. This sector implies that these industries' outputs have used as inputs for other's industrial production. Moreover, there has seen that most sectors are weak-oriented sectors during the three years. 
Figure 2: Key Sectors of Cambodia in 2005

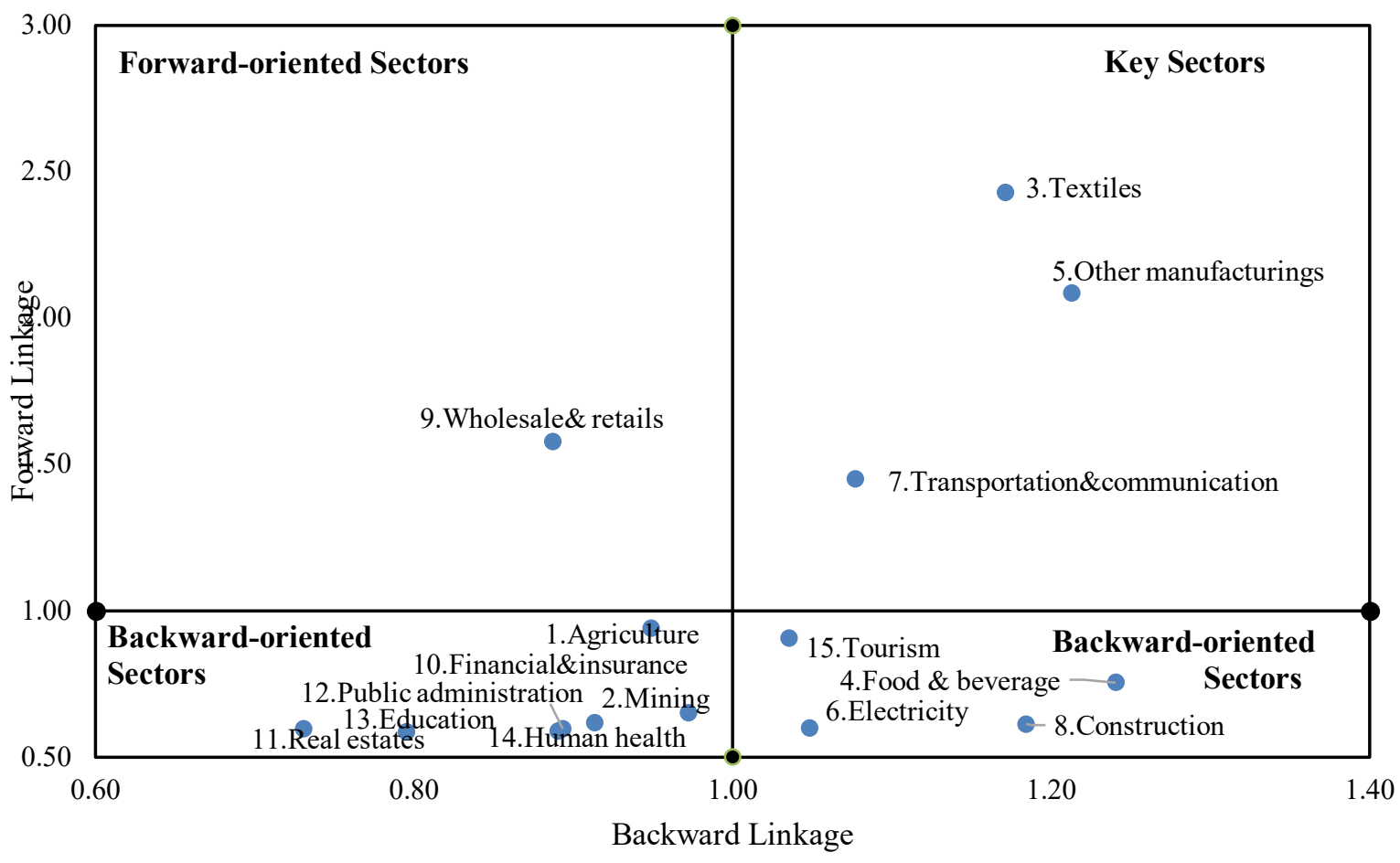

Source: Author's calculation

Figure 3: Key Sectors in 2010

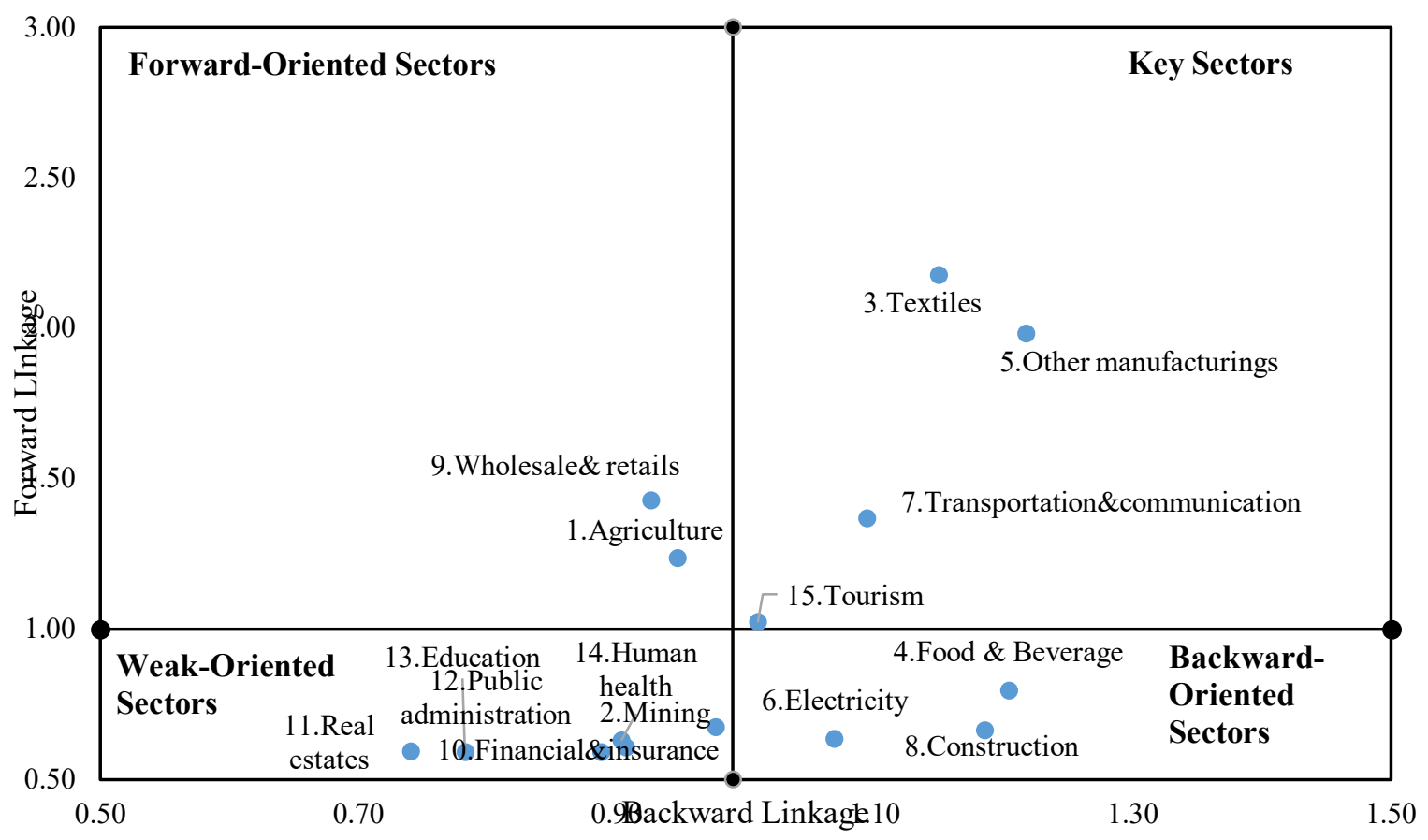

Source: Author's calculation 
Figure 4: Key Sectors of Cambodia in 2015

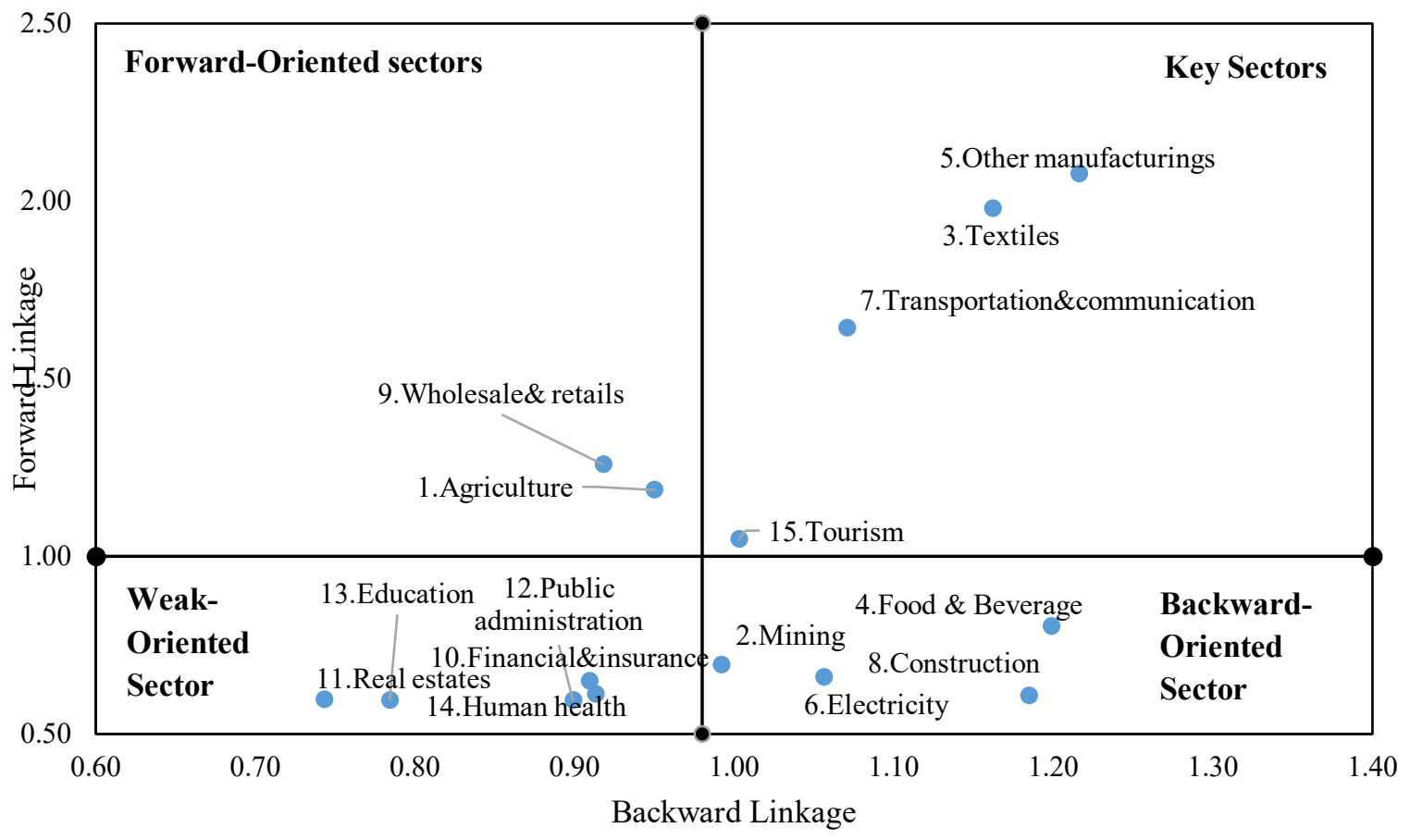

Source: Author's calculation

\subsection{The Landscape of Cambodian Economy}

Figure 5-7 illustrates the Cambodian economic landscape for three years $(2005,2010$, and 2015). The graph shows the relationship between structural industries through the hierarchy of forward-and- backward linkage.

In 2005, the landscape economy presented a considerable variation of inter-sectoral linkages, implying a low inter-industry linkage among sectors. The hierarchy of the highest bar was the intersection between the food and beverage and textile sector. This conjunction indicates that industrialization played an essential role in Cambodia's economy. The third and four apexes were at the interconnection of economic areas 8-9 (wholesale and retail-construction) and 3-7 (textiles-transportation and communication). This link pinpoints that the manufacturing and service sectors become active in the economy. Also, the sixth and seventh apexes showed the intersection of industries 6-15 (electricity-tourism) and 15-4 (tourism- 
food and beverage). These sectors have similar height, indicating that the tourism, electricity, and food and beverage sector have a strong inter-link with other industries in the rest of the economy.

Figure 6 showed Cambodia's economic landscape in 2010. The highest bar is the junction of sector 5-3 (other manufacturing-textile), and the second apex is the intersection of industry 4 (food and beverage) and 5 (other manufacture). This linkage reflects the process of industrialization in Cambodia's economy remains essential for the economic development in Cambodia. The third and four apexes are at the interaction of sectors 8-9 (wholesale and retail-construction) and 3-7 (textiles-transportation and communication). This interaction presents an active role of sectors in the economy. Also, the sixth and seventh apexes are at the junction of the industry 6-15 (electricity-tourism) and 15-4 (tourism-food and beverage). The height of these sectors has relatively more variation than in 2005 , presenting a low association between tourism, electricity, and food and beverage. Thus, there is a shortage of domestic products supplied to the tourism sector when tourism expands. The economic landscape of Cambodia in 2010 shows a considerable variation in inter-industry linkages.

Similarly, figure 7 exhibits the Cambodia economic landscape in 2015. The highest bar is the junction of sector 5 (other manufacturing) and itself. It followed by the intersection of industry 4-3 (food and beverages-textiles). The third and four apexes are at the inter-link of sectors 8-7 (construction-transportation and communication) and 3-9 (textiles-wholesale and retail), followed by the fifth apex of the inter-industry linkage between industry 7 (transportation and communication) and sector 1 (agriculture). This interaction indicates that agriculture, other manufacturing, and service sector are actively economic performance in 
the economy. Also, the association between tourism and other economic segments did not change in 2015. The economic landscape of Cambodia in 2015 shows a significant variation in inter-industry linkages.

Figure 5: Economic Landscape of Cambodian Economy in 2005

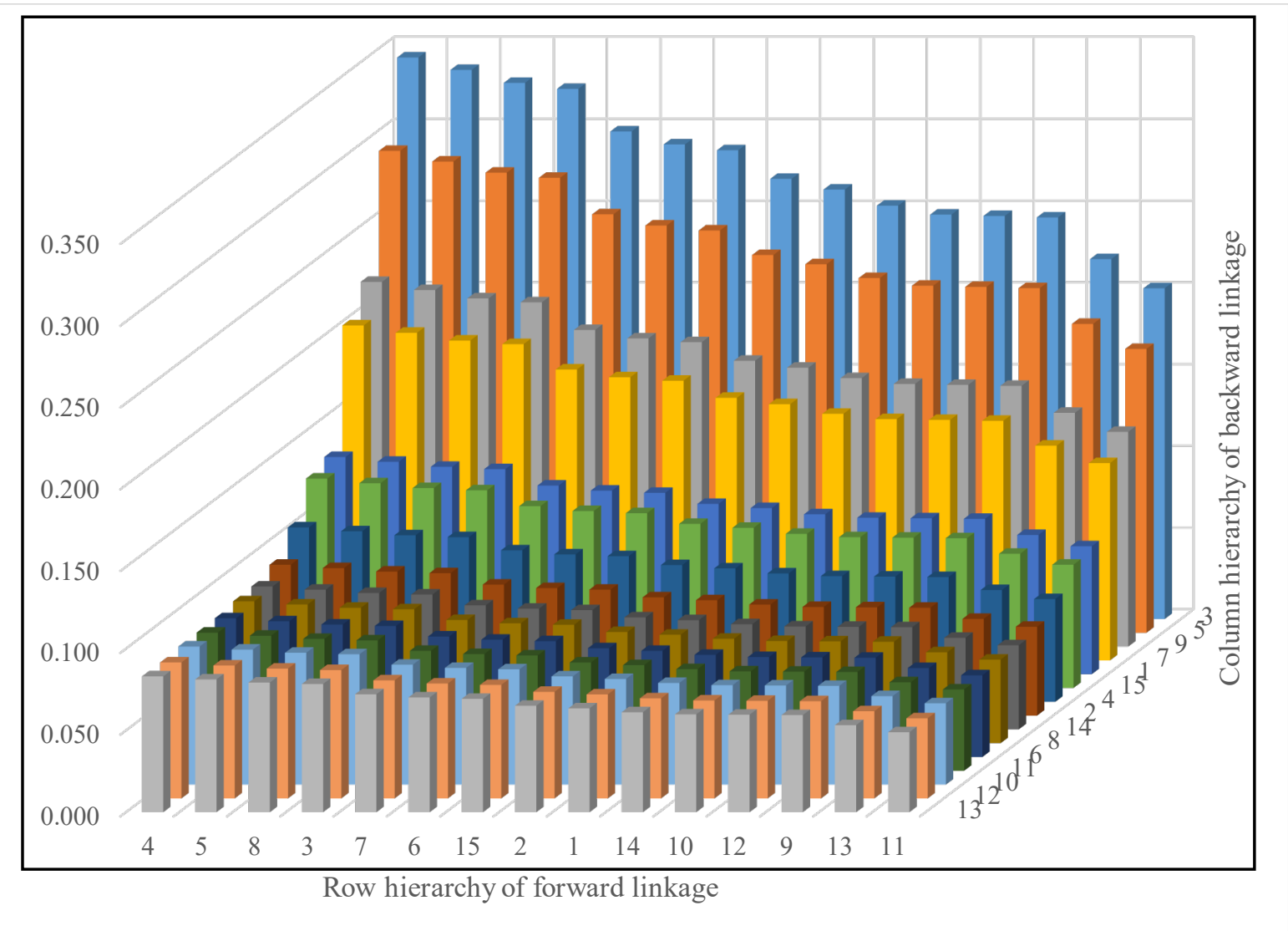

Source: Author's illustration 
Figure 6: Economic Landscape of Cambodian Economy in 2010

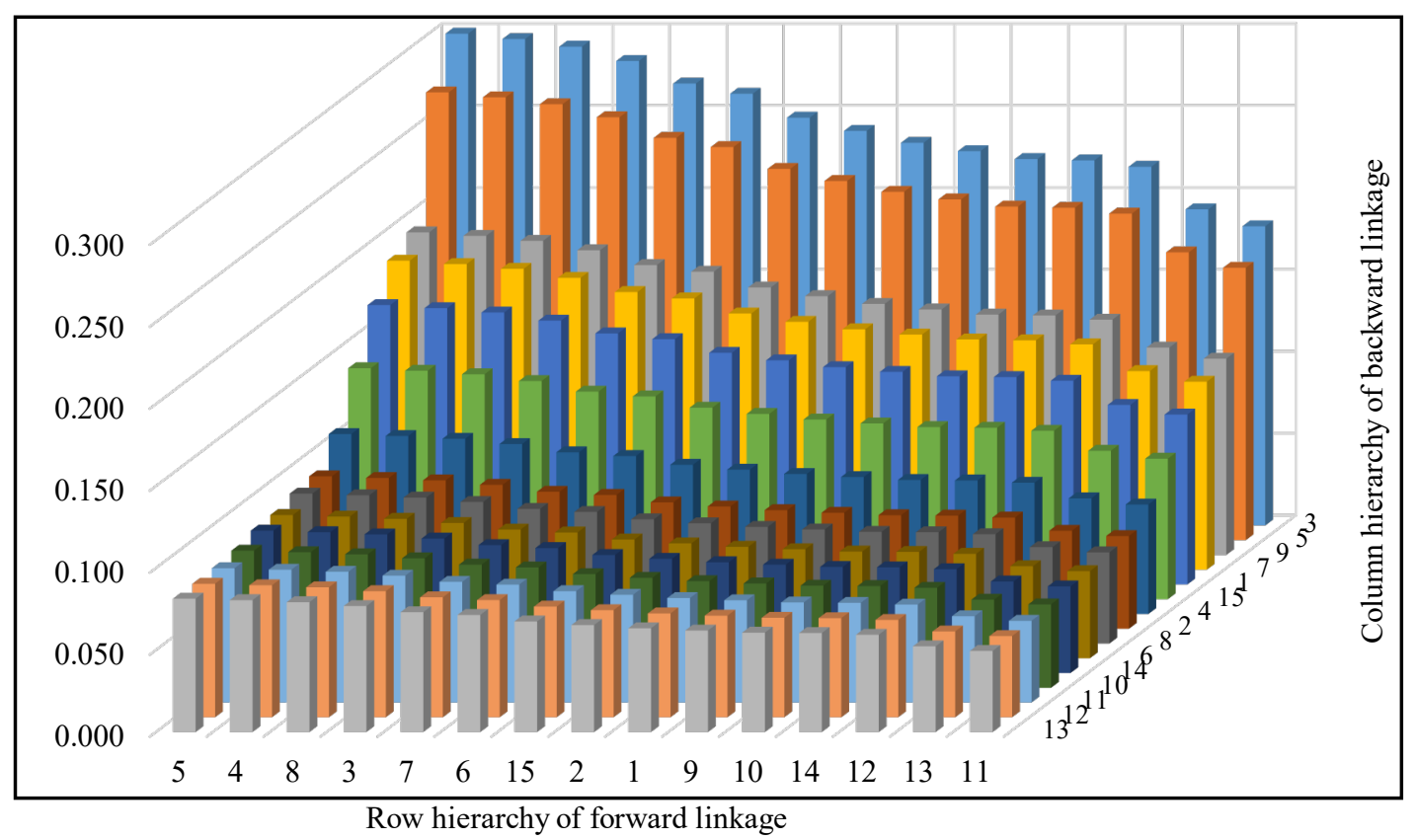

Source: Author's illustration

Figure 7: Economic Landscape of Cambodian Economy in 2015

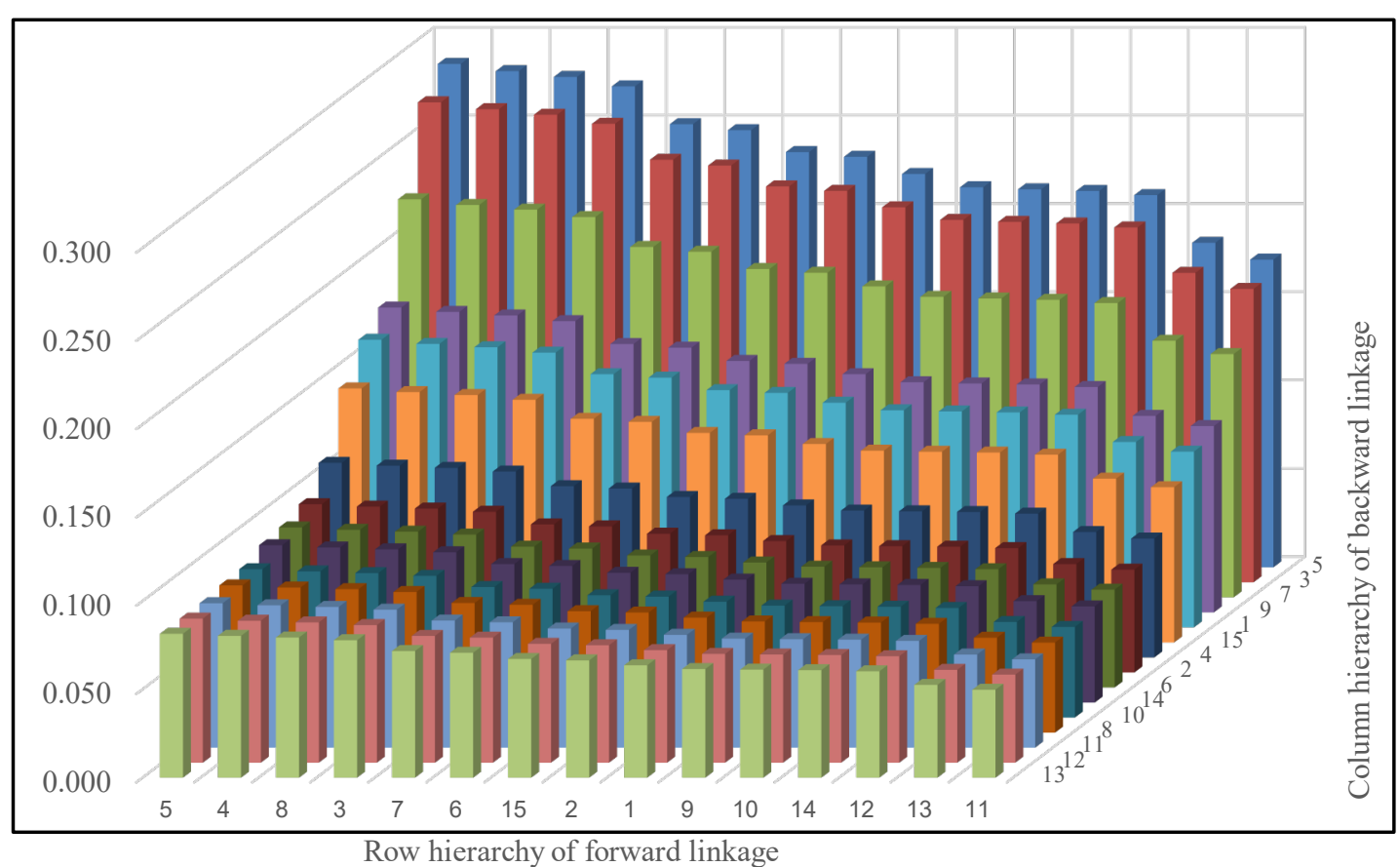

Source: Author's illustration 


\subsection{Field of Influence}

We use the Field of influence approach to further investigate the sectors' interdependences for the years 2005, 2010, and 2015, in addition to the linkage analysis. Each productive linkage highlighted as the color scales. The blank box and lighter color note the value of coefficients below the mean and above mean plus a standard deviation, respectively. The intermediate color marks between one and two standard deviations. The darker blue color marks the above two standard deviations. The result presented in figure 8 . Three industries, namely, textile (sector 3), other manufacturing (sector 5), and transportation and communication (sector 7), reveal the most significant coefficient of the field of influence of changes during the three years. These sectors present more importance in the economy. At the same time, the rest of the industries have relatively lost the critical coefficient of fields of influence over the examined periods.

In terms of linkages, the agriculture industry has intensively interconnected (above two standard deviations) with the textile sector in 2015, and intermediated linkage in the rest of two years. The textile industry has integrated into the production process within the industry itself, and the most robust strength linkage (above average plus two standard deviations) with other manufacturing, and transportation and communication. Interestingly, the wholesale and retail sector presents the most substantial ties above average plus two standard deviations with the textile sector in 2005 and 2010, but less intensity in 2015. The tourism sector is a relatively weak linkage with other industries over the periods.

\section{Conclusion}

This study uses an input-output table of three years $(2005,2010$, and 2015) to investigate the dynamic inter-sectorial linkages of the tourism sector and structural economic changes in 
Cambodia. This paper employs the multiplier product matrix and Field of influence approaches.

We find that seven out of fifteen sectors (namely, food and beverage, other manufacturing, construction, textile, transportation and communication, electricity, and tourism) show higher backward linkage during 2005-2015. Sectors, such as textiles, other manufacturing, transportation, and wholesale and retail, exhibit the top four strong forward linkages. The tourism sector moved to be the top 5 highest forward linkages in 2010 and 2015. Moreover, most service sectors (e.g., wholesale and retail, financial and insurance, real estate, public administration, education, and human health) demonstrate weak backward linkage.

The paper also confirmed that the overall inter-industry linkage is relatively low during the observed periods. The textile, other manufacturing, and transportation and communication have the largest coefficient Field of influence of changes in the economy. This sector has well interconnected with other economies. In contrast, tourism is a relatively promising sector concerning low Fields of Influence of Changes in the rest of industries.

This study may suggest that there would be a need for promoting, encouraging, and investing in key economic sectors, as well as increasing domestic production. We also suggest that policy intervention should focus on creating the development of linkages, which help to reduce imports of tourism goods and services. 
Figure 8: Fields of Influence in 2005, 2010, and 2015 for Cambodia.

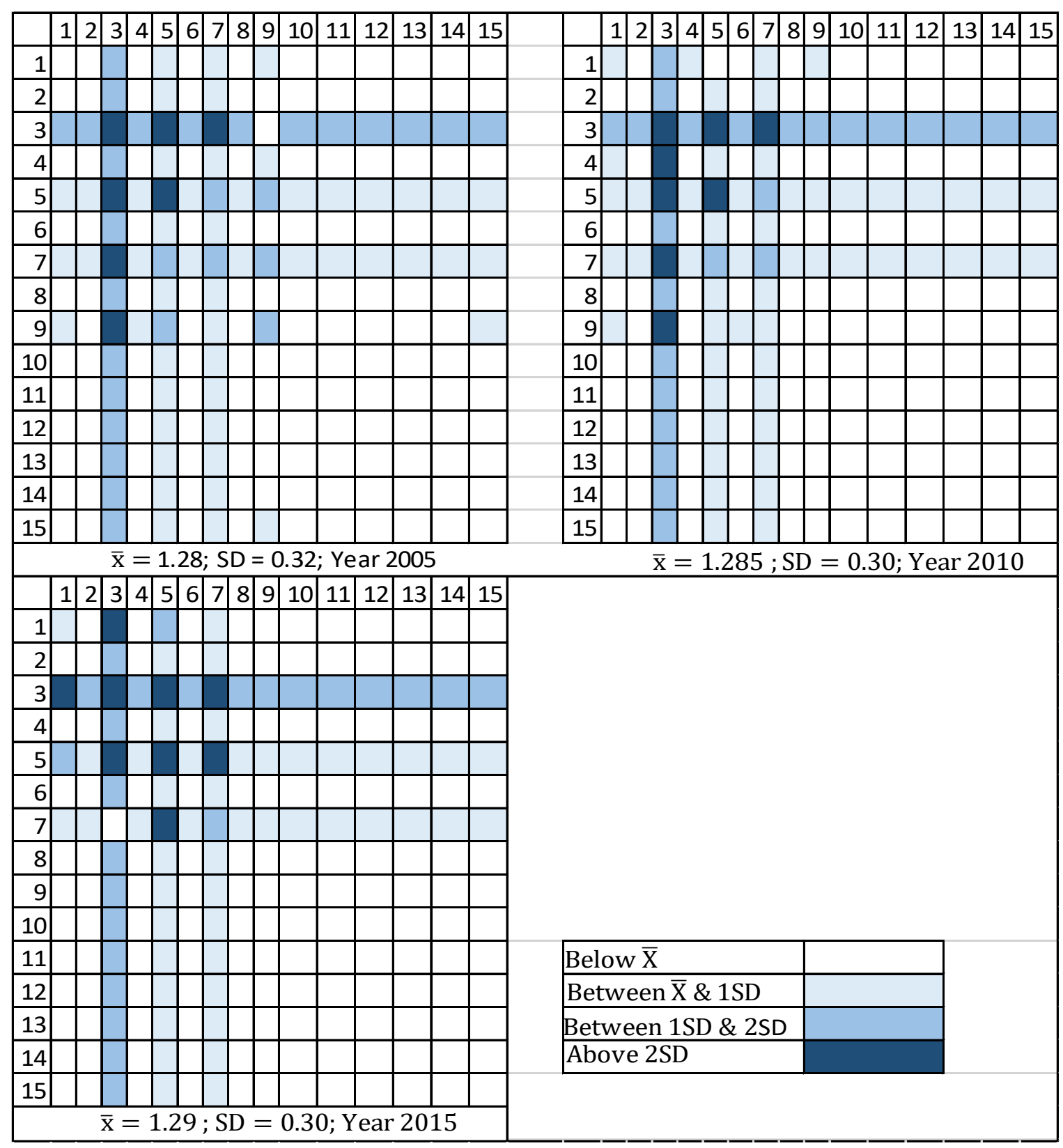

Source: Author's calculation 


\section{Appendix:}

Table 1: List of aggregated sectors in the study

\section{Agriculture}

1. Agriculture, hunting, forestry, and fishing

2. Mining and quarrying

2. Mining and extraction of energy-producing products

3. Mining and quarry of non-energy producing products

4. Mining support service activities

3. Textile

5. Textile, wearing apparel, leather, and related products

4. Food and Beverage

6. Food products, beverages, and related-products

5. Other manufacturing

7. Wood and of products of wood and cork (except furniture)

8. Paper products and printing

9. Coke and refined petroleum products

10. Chemicals and pharmaceutical products

11. Rubber and plastics products

12. Other non-metallic mineral products

13. Manufacture of basic metals

14. Fabricate metal products, except machinery and equipment

15. Computer, electronic and optical products

16. Electrical equipment

17. machinery and equipment

18. Motor vehicles, trailers, and semi-trailers

19. Other transport equipment

20. Other manufacturing; repair and installation of machinery and equipment

\section{Electricity}

21. Electricity, gas, water supply, sewerage, waste, and remediation service

7. Transportation and Telecommunication

22. Transportation and storage

23. Telecommunications

24. Publishing, audio-visual and broadcasting activities

25. IT and other information services

8. Construction

26. Construction

9. Wholesale and Retail

27. Wholesale and retail trade; repair of motor vehicles

10. Financial and insurance

28. Financial and insurance

11. Real estate

29. Real estate activities

12. Public administration

30. Public administration and defense; compulsory social security

\section{Education}

\section{Education}

14. Human health and social work

32. Human health and social work

\section{Tourism}

33. Accommodation and food services

34. Arts, entertainment, recreation, and other service activities

35. Other business sector services 
Table 2: Cambodia's Industrial Structure, 2005-2015

\begin{tabular}{|c|c|c|c|c|c|c|c|c|c|}
\hline \multirow{2}{*}{ Sectors } & \multicolumn{3}{|c|}{$\%$ Gross Output } & \multicolumn{3}{|c|}{$\%$ GDP } & \multicolumn{3}{|c|}{$\%$ Value Added } \\
\hline & 2005 & 2010 & 2015 & 2005 & 2010 & 2015 & 2005 & 2010 & 2015 \\
\hline 1.Agriculture & 30.1 & 28.1 & 29.1 & 25.6 & 26.5 & 26.1 & 30.4 & 30.5 & 28.1 \\
\hline 2.Mining and Quarrying & 0.1 & 0.1 & 0.1 & 0.3 & 0.4 & 0.5 & 0.4 & 0.4 & 0.5 \\
\hline 3.Textiles & 9.3 & 7.2 & 8.8 & 14.0 & 11.1 & 11.5 & 11.5 & 8.4 & 8.9 \\
\hline 4.Food and beverage & 11.7 & 11.0 & 11.1 & 8.6 & 8.1 & 8.0 & 5.9 & 6.2 & 5.1 \\
\hline 5.Other manufacturing & 9.4 & 12.7 & 13.5 & 12.5 & 14.4 & 15.4 & 9.6 & 10.8 & 10.6 \\
\hline 6.Electricity & 0.7 & 1.1 & 1.2 & 0.8 & 1.1 & 1.0 & 0.8 & 1.1 & 0.9 \\
\hline 7.Transportation and communication & 10.1 & 9.7 & 10.7 & 6.8 & 6.7 & 6.9 & 5.7 & 5.5 & 5.4 \\
\hline 8.Construction & 5.5 & 6.8 & 4.2 & 7.4 & 7.7 & 6.7 & 5.8 & 7.3 & 11.0 \\
\hline 9.Wholesale and retail & 3.8 & 4.6 & 6.2 & 7.4 & 7.7 & 8.1 & 9.3 & 9.2 & 9.3 \\
\hline 10.Financial and insurance & 1.0 & 1.3 & 1.4 & 0.9 & 1.0 & 1.1 & 1.1 & 1.3 & 1.3 \\
\hline 11.Real estates & 4.4 & 4.6 & 4.7 & 3.9 & 4.0 & 4.0 & 6.1 & 6.2 & 5.9 \\
\hline 12.Public administration & 1.6 & 1.6 & 1.7 & 1.2 & 1.2 & 1.3 & 1.6 & 1.6 & 1.6 \\
\hline 13.Education & 1.6 & 1.5 & 1.6 & 1.4 & 1.3 & 1.3 & 2.0 & 1.9 & 1.9 \\
\hline 14.Human health & 1.1 & 1.0 & 1.3 & 1.0 & 0.9 & 1.1 & 1.2 & 1.1 & 1.4 \\
\hline 15. Tourism & 9.7 & 8.8 & 8.2 & 8.2 & 7.7 & 7.0 & 8.6 & 8.5 & 8.2 \\
\hline Accommodation and food services & 4.9 & 4.4 & 4.3 & 4.0 & 3.9 & 3.5 & 4.1 & 4.2 & 4.3 \\
\hline Arts, entertainment, recreation, and other service activities & 3.9 & 3.3 & 1.8 & 3.2 & 2.8 & 1.4 & 3.3 & 3.1 & 2.4 \\
\hline Other business sector services & 0.9 & 1.1 & 2.1 & 1.0 & 1.0 & 2.1 & 1.2 & 1.3 & 1.5 \\
\hline Total & 100 & 100 & 104 & 100 & 100 & 100 & 100 & 100 & 100 \\
\hline
\end{tabular}

Source: Author's Calculation from Input-Output Table 
Table 3: The Structure of Cambodia's Import-Export, 2005-2015

\begin{tabular}{|c|c|c|c|c|c|c|c|c|c|c|c|c|}
\hline \multirow{2}{*}{ Sectors } & \multicolumn{3}{|c|}{$\%$ Export } & \multicolumn{3}{|c|}{ \% Import } & \multicolumn{3}{|c|}{ Export Intensity } & \multicolumn{3}{|c|}{ Import Intensity } \\
\hline & 2005 & 2010 & 2015 & 2005 & 2010 & 2015 & 2005 & 2010 & 2015 & 2005 & 2010 & 2015 \\
\hline 1.Agriculture & 36.6 & 20.8 & 23.5 & 1.1 & 0.5 & 0.9 & 45.9 & 19.2 & 23.6 & 1.6 & 0.5 & 1.1 \\
\hline 2.Mining and Quarrying & 0.0 & 0.2 & 0.5 & 0.3 & 0.6 & 0.9 & 4.3 & 9.8 & 30.5 & 36.9 & 46.3 & 60.8 \\
\hline 3.Textile & 25.7 & 22.4 & 22.6 & 29.1 & 27.7 & 21.8 & 59.1 & 49.1 & 51.5 & 78.2 & 70.1 & 58.0 \\
\hline 4.Food and beverage & 6.7 & 7.0 & 6.9 & 3.7 & 4.1 & 4.0 & 24.9 & 21.0 & 22.7 & 16.3 & 14.3 & 15.4 \\
\hline 5.Other manufacturing & 15.9 & 25.6 & 21.7 & 41.3 & 39.4 & 36.4 & 40.8 & 43.4 & 37.0 & 124.0 & 76.9 & 72.5 \\
\hline 6.Electricity & 0.0 & 0.0 & 0.0 & 1.5 & 2.2 & 2.1 & 0.0 & 0.0 & 0.0 & 66.6 & 57.4 & 62.6 \\
\hline 7.Transportation and communication & 0.0 & 0.0 & 0.0 & 0.0 & 0.0 & 0.0 & 0.0 & 0.0 & 0.0 & 0.1 & 0.1 & 0.1 \\
\hline 8.Construction & 5.5 & 12.2 & 10.8 & 10.5 & 10.4 & 19.0 & 23.9 & 38.5 & 42.4 & 53.0 & 38.0 & 87.3 \\
\hline 9.Wholesale and retail & 5.5 & 5.8 & 6.4 & 11.0 & 12.4 & 7.7 & 23.9 & 18.5 & 20.5 & 55.7 & 45.3 & 28.9 \\
\hline 10.Financial and insurance & 0.3 & 0.2 & 0.7 & 0.7 & 0.8 & 1.1 & 9.7 & 5.6 & 16.8 & 31.3 & 20.3 & 30.8 \\
\hline 11.Real estate & 0.4 & 0.5 & 0.7 & 0.1 & 0.2 & 0.5 & 3.1 & 3.0 & 4.4 & 0.6 & 1.1 & 4.0 \\
\hline 12.Public administration & 0.0 & 0.0 & 0.0 & 0.0 & 0.0 & 0.0 & 0.0 & 0.0 & 0.0 & 0.5 & 0.3 & 0.7 \\
\hline 13.Education & 0.1 & 0.1 & 0.2 & 0.0 & 0.1 & 0.5 & 2.6 & 2.6 & 4.6 & 0.8 & 3.1 & 11.8 \\
\hline 14.Human health & 0.1 & 0.1 & 0.1 & 0.0 & 0.0 & 0.1 & 3.1 & 3.0 & 3.4 & 0.6 & 1.3 & 3.8 \\
\hline 15.Tourism & 3.3 & 4.9 & 5.9 & 0.8 & 1.5 & 4.8 & 42.5 & 59.2 & 62.6 & 22.4 & 18.3 & 56.4 \\
\hline Accommodation and food services & 2.4 & 2.9 & 3.9 & 0.2 & 1.0 & 3.5 & 19.0 & 18.4 & 29.5 & 2.0 & 7.5 & 30.6 \\
\hline $\begin{array}{l}\text { Arts, entertainment, recreation } \\
\& \text { other service activities }\end{array}$ & 0.4 & 0.5 & 1.4 & 0.1 & 0.2 & 0.8 & 3.7 & 3.9 & 25.9 & 0.6 & 1.5 & 18.5 \\
\hline Other business sector services & 0.6 & 1.6 & 0.6 & 0.5 & 0.3 & 0.5 & 19.9 & 37.0 & 7.2 & 19.8 & 9.3 & 7.3 \\
\hline Total & 100 & 100 & 100 & 100 & 100 & 100 & & & & & & \\
\hline
\end{tabular}

Source: Author's Calculation from Input-Output Table 
Table 4: Sector's Share of Labor Income and its Intensity, 2005-2015

\begin{tabular}{|l|c|c|c|c|c|c|}
\hline \multirow{2}{*}{ Sectors } & \multicolumn{3}{c|}{ Labour Income } & \multicolumn{3}{c|}{ Labour Income Intensity } \\
\cline { 2 - 6 } & 2005 & 2010 & 2015 & 2005 & 2010 & 2015 \\
\hline 1.Agriculture & 31.73 & 31.27 & 27.67 & 26.65 & 26.54 & 26.25 \\
\hline 2.Mining and Quarrying & 0.39 & 0.35 & 0.35 & 25.59 & 20.20 & 19.31 \\
\hline 3.Textile & 9.36 & 5.56 & 6.85 & 14.42 & 11.23 & 14.71 \\
\hline 4.Food and beverage & 6.06 & 7.31 & 4.95 & 15.13 & 20.21 & 15.31 \\
\hline 5.Other manufacturing & 11.69 & 12.65 & 12.47 & 20.11 & 19.75 & 20.06 \\
\hline 6.Electricity & 0.66 & 0.82 & 0.71 & 17.44 & 17.24 & 17.17 \\
\hline 7.Transportation and communication & 8.79 & 8.32 & 7.78 & 27.88 & 28.02 & 28.04 \\
\hline 8.Construction & 1.81 & 5.29 & 12.47 & 5.25 & 15.38 & 46.27 \\
\hline 9.Wholesale and retail & 9.19 & 8.88 & 8.66 & 26.69 & 25.96 & 26.32 \\
\hline 10.Financial and insurance & 0.60 & 0.70 & 0.67 & 14.99 & 15.03 & 15.22 \\
\hline 11.Real estate & 3.23 & 3.19 & 2.94 & 17.64 & 17.85 & 18.18 \\
\hline 12.Public administration & 3.89 & 3.74 & 3.52 & 66.92 & 67.36 & 66.15 \\
\hline 13.Education & 3.75 & 3.52 & 3.30 & 58.29 & 60.78 & 65.26 \\
\hline 14.Human health & 0.59 & 0.54 & 0.64 & 13.22 & 13.62 & 13.78 \\
\hline 15. Tourism & 8.27 & 7.86 & 7.02 & 27.30 & 28.52 & 34.00 \\
\hline Accommodation and food services & 0.84 & 0.84 & 0.84 & 4.52 & 4.87 & 5.96 \\
\hline Arts, entertainment, recreation, and other service activities & 5.69 & 5.21 & 3.92 & 38.27 & 41.23 & 69.58 \\
\hline Other business sector services & 1.74 & 1.80 & 2.26 & 39.11 & 39.46 & 26.46 \\
\hline Total & 100 & 100 & 100 & & & \\
\hline Source Authoryyyyyyyyyyyyy
\end{tabular}

Source: Author's Calculation from Input-Output Table 
Table 5: The Structure of Final Demand in Cambodia's Economy, 2005-2015

\begin{tabular}{|c|c|c|c|c|c|c|c|c|c|c|c|c|}
\hline \multirow[t]{2}{*}{ Sectors } & \multicolumn{3}{|c|}{ Private Consumption } & \multicolumn{3}{|c|}{$\begin{array}{l}\text { Government } \\
\text { Consumption }\end{array}$} & \multicolumn{3}{|c|}{ Investment } & \multicolumn{3}{|c|}{ Net Export } \\
\hline & 2005 & 2010 & 2015 & 2005 & 2010 & 2015 & 2005 & 2010 & 2015 & 2005 & 2010 & 2015 \\
\hline 1.Agriculture & 17.79 & 24.15 & 22.87 & 0.10 & 0.18 & 0.18 & 0.24 & 0.28 & 0.34 & 19.56 & 8.71 & 10.37 \\
\hline 2.Mining and Quarrying & 0.13 & 0.15 & 0.15 & 0.00 & 0.01 & 0.01 & 0.03 & 0.02 & 0.03 & -0.19 & -0.25 & -0.24 \\
\hline 3.Textile & 7.85 & 6.16 & 5.33 & 0.08 & 0.19 & 0.11 & 0.17 & 0.24 & 0.30 & -4.60 & -4.10 & -1.32 \\
\hline 4.Food and beverage & 10.10 & 9.58 & 9.22 & 0.01 & 0.02 & 0.01 & 0.00 & 0.00 & 0.00 & 1.28 & 0.96 & 1.03 \\
\hline 5.Other manufacturing & 14.28 & 10.85 & 10.63 & 0.75 & 0.56 & 0.28 & 7.03 & 4.98 & 6.28 & -17.97 & -8.49 & -9.64 \\
\hline 6.Electricity & 1.49 & 2.06 & 2.21 & 0.00 & 0.08 & 0.13 & 0.01 & 0.00 & 0.01 & -0.94 & -1.09 & -1.14 \\
\hline 7.Construction & 6.31 & 4.52 & 5.03 & 0.68 & 0.67 & 0.73 & 0.46 & 0.33 & 1.10 & -3.73 & 0.07 & -5.29 \\
\hline $\begin{array}{l}\text { 8.Transportation and } \\
\text { communication }\end{array}$ & 0.50 & 0.58 & 0.53 & 0.00 & 0.00 & 0.00 & 10.88 & 10.3 & 11.4 & -0.01 & -0.01 & -0.01 \\
\hline 9. Wholesale and retails & 5.77 & 6.62 & 6.44 & 0.14 & 0.15 & 0.07 & 0.91 & 0.69 & 0.80 & -4.06 & -3.63 & -1.21 \\
\hline 10.Financial and insurance & 1.69 & 1.99 & 2.02 & 0.00 & 0.00 & 0.00 & 0.00 & 0.00 & 0.00 & -0.32 & -0.27 & -0.27 \\
\hline 11.Real estates & 6.46 & 6.88 & 6.97 & 0.01 & 0.00 & 0.00 & 0.03 & 0.01 & 0.02 & 0.17 & 0.14 & 0.03 \\
\hline 12.Public administration & 0.03 & 0.04 & 0.04 & 2.11 & 2.15 & 2.27 & 0.00 & 0.00 & 0.00 & -0.01 & -0.01 & -0.02 \\
\hline 13.Education & 1.65 & 1.61 & 1.58 & 0.68 & 0.68 & 0.77 & 0.00 & 0.00 & 0.00 & 0.04 & -0.01 & -0.16 \\
\hline 14.Human health & 1.43 & 1.14 & 1.64 & 0.00 & 0.19 & 0.00 & 0.00 & 0.00 & 0.02 & 0.04 & 0.03 & -0.01 \\
\hline 15. Tourism & 7.90 & 5.14 & 6.19 & 1.43 & 3.16 & 1.59 & 0.27 & 0.23 & 0.49 & 1.35 & 1.36 & 0.11 \\
\hline $\begin{array}{l}\text { Accommodation and } \\
\text { food services }\end{array}$ & 4.02 & 3.31 & 3.64 & 0.31 & 0.65 & 0.49 & 0.00 & 0.00 & 0.00 & 1.17 & 0.74 & -0.07 \\
\hline $\begin{array}{l}\text { Arts, entertainment, } \\
\text { recreation and other } \\
\text { service activities }\end{array}$ & 3.14 & 1.19 & 0.73 & 1.04 & 2.42 & 0.07 & 0.05 & 0.06 & 0.39 & 0.17 & 0.12 & 0.18 \\
\hline $\begin{array}{l}\text { Other business sectors } \\
\text { services }\end{array}$ & 0.74 & 0.64 & 1.82 & 0.08 & 0.08 & 1.02 & 0.21 & 0.17 & 0.10 & 0.00 & 0.50 & 0.00 \\
\hline Total & 83.37 & 81.47 & 80.84 & 5.98 & 8.04 & 6.15 & 20.03 & 17.1 & 20.79 & -9.38 & -6.59 & -7.78 \\
\hline
\end{tabular}

Source: Author's Calculation from Input-Output Table 
Table 6: The Results of Backward and Forward Linkages

\begin{tabular}{|c|c|c|c|c|c|c|c|c|c|c|c|c|}
\hline \multirow{3}{*}{ Sectors } & \multicolumn{6}{|c|}{ Backward Linkages } & \multicolumn{6}{|c|}{ Forward Linkages } \\
\hline & \multicolumn{2}{|c|}{2005} & \multicolumn{2}{|c|}{2010} & \multicolumn{2}{|c|}{2015} & \multicolumn{2}{|c|}{2005} & \multicolumn{2}{|c|}{2010} & \multicolumn{2}{|c|}{2015} \\
\hline & Value & Rank & Value & Rank & Value & Rank & Value & Rank & Value & Rank & Value & Rank \\
\hline 1.Agriculture & 0.95 & 9 & 0.95 & 9 & 0.95 & 9 & 0.94 & 5 & 1.24 & 5 & 1.19 & 5 \\
\hline 2.Mining and quarrying & 0.97 & 8 & 0.98 & 8 & 0.99 & 8 & 0.65 & 8 & 0.67 & 8 & 0.69 & 8 \\
\hline 3.Textile & 1.17 & 4 & 1.15 & 4 & 1.16 & 4 & 2.43 & 1 & 2.18 & 1 & 1.98 & 2 \\
\hline 4.Food and beverages & 1.24 & 1 & 1.20 & 2 & 1.20 & 2 & 0.75 & 7 & 0.80 & 7 & 0.80 & 7 \\
\hline 5.Other manufacturing & 1.21 & 2 & 1.22 & 1 & 1.22 & 1 & 2.09 & 2 & 1.98 & 2 & 2.08 & 1 \\
\hline 6.Electricity & 1.05 & 6 & 1.07 & 6 & 1.06 & 6 & 0.60 & 11 & 0.63 & 10 & 0.66 & 9 \\
\hline $\begin{array}{l}\text { 7.Transportation and } \\
\text { Communication }\end{array}$ & 1.08 & 5 & 1.09 & 5 & 1.07 & 5 & 1.45 & 4 & 1.37 & 4 & 1.64 & 3 \\
\hline 8.Construction & 1.18 & 3 & 1.19 & 3 & 1.18 & 3 & 0.61 & 10 & 0.66 & 9 & 0.61 & 12 \\
\hline 9. Wholesale and retail & 0.89 & 13 & 0.93 & 10 & 0.92 & 10 & 1.58 & 3 & 1.43 & 3 & 1.26 & 4 \\
\hline 10.Financial and insurance & 0.89 & 11 & 0.91 & 11 & 0.91 & 11 & 0.60 & 13 & 0.61 & 12 & 0.61 & 11 \\
\hline 11.Real estate activities & 0.73 & 15 & 0.74 & 15 & 0.74 & 15 & 0.60 & 12 & 0.59 & 13 & 0.60 & 13 \\
\hline 12.Public administration & 0.89 & 12 & 0.89 & 13 & 0.90 & 13 & 0.59 & 14 & 0.59 & 14 & 0.59 & 14 \\
\hline 13.Education & 0.80 & 14 & 0.78 & 14 & 0.78 & 14 & 0.59 & 15 & 0.59 & 15 & 0.59 & 15 \\
\hline 14.Human health & 0.91 & 10 & 0.90 & 12 & 0.91 & 12 & 0.62 & 9 & 0.63 & 11 & 0.65 & 10 \\
\hline 15.Tourism & 1.04 & 7 & 1.01 & 7 & 1.00 & 7 & 0.91 & 6 & 1.02 & 6 & 1.05 & 6 \\
\hline
\end{tabular}

Source: Author's Calculation from Input-Output Table 


\section{Acknowledgments}

The author would like to thank Associate Professor OTCHIA Christian Samen from the Graduate School of International Development, Nagoya University, for his valuable comments and suggestions on the methodology.

\section{Authors' contributions}

The author read and approved the final manuscript.

\section{Funding}

Not applicable

\section{Availability of data and materials}

This study uses the input-output tables obtaining from the IO OECD database. The tables are available to download at https://stats.oecd.org/Index.aspx?DataSetCode=IOTSI4_2018.

\section{Competing interests}

The author declares no competing interests. 


\section{References}

Akkemik K (2012) Assessing the importance of international tourism for the Turkish economy: A social accounting matrix analysis. Tourism Management 33(4):790-801

Antara M, Sumarniasih M (2018) Role of tourism in the economy of Bali and Indonesia. Journal of Tourism and Hospitality Management 5(2):34-44

Archer B, Fletcher J (1996) The economic impact of tourism in Seychelles. Annals of Tourism Research 23(1):32-47

Asian Development Bank (2009) Strengthening Sustainable Tourism. Retrieved from http://www.gms-eoc.org/uploads/resources/30/attachment/Strengthening

Sustainable Tourism - SEA of the Tourism Sector in Cambodia.pdf

Asian Development Bank (2019) Key indicators for Asia and the Pacific 2019 https://data.adb.org/dataset/Cambodia-key-indicators. Accessed 14 Jan 2020

Asuyama Y, Neou S (2012) How Has the Cambodian Garment Industry Evolved ?. In: Fukunishi (ed) Dynamics of the Garment Industry in Low-Income Countries: Experience of Asia and Africa, IDE-JETERO

Atan S, Arslanturk Y (2012) Tourism and economic growth nexus: an input-output analysis in Turkey. Procedia - Social and Behavioral Sciences 62:952-956

Banerjee O, Cicowiez M, Cotta J (2016) Economics of tourism investment in scarce data countries. Annals of Tourism Research 60:115-138

Cai J, Leung P, Mak J (2006) Tourism's forward and backward linkages. Journal of Travel Research 45(1):36-52

Carrascal A, Fernández M (2015) Tourism and income distribution: evidence from a developed regional economy. Tourism Management 48:11-20

Celia G (1984) The Input-Output measurement of interindustry linkages. Oxford Bulletin of economics and statistics 46(1):73-84

Chaivichayachat B (2017) Inter-industry linkage of tourism-related sectors in Thailand: Past, present, and future. Information 20(10):7191-7198

Chenery H, Watanabe T (1958) International Comparisons of the Structure of Production. Econometrica 26(4):487-521

Chheang V (2008) State and tourism planning: a case study of Cambodia. MPRA Paper No.25306.https://mpra.ub.uni-muenchen.de/25306/1/MPRA_paper_25306.pdf. Accessed 14 Jan 2020

Chhorn T (2017) On the investigation of factors affecting international tourist arrivals to the Cambodian market: A Static and Dynamic Gravity Approach 5:115-138

Chhuor S (2017) Potential roles of the export orientation of Cambodia's agriculture and agroindustry: an application of CGE analysis. Journal of Economic Structures 6(1)

Defourny J, Thorbecke E (1984) Structural path analysis and multiplier decomposition within a social accounting matrix framework. The Economic Journal 94(373):111-136

Dwyer L, Forsyth P, Spurr R (2003) Inter-industry effects of tourism growth: implications for destination managers. Tourism Economics 9(2):117-132

Ferrari G, Mondéjar J, Secondi L (2018) Tourists' Expenditure in Tuscany and its impact on the regional economic system. Journal of Cleaner Production 171:1437-1446 
Freeman D, Sultan E (1997) The economic impact of tourism in Israel: a multi-regional input-output analysis. Tourism Economics 3(4): 341-359 doi:https://doi.org/10.1177/135481669700300404

Gabriel L (2019) Economic growth and manufacturing: An analysis using panel VAR and intersectoral linkages. Structural Change and Economic Dynamics 49:43-61

Grosso G, Lesher M, Pinali E (2007) Service trade liberalization and tourism development. https://doi.org/10.1787/18166873. OECD trade policy papers No.57 Posted November 2007

Henry E, Deane B (1997) The contribution of tourism to the economy of Ireland in 1990 and 1995. Tourism Management 18(8):535-553

Hirschman A (1958) The strategy of economic development, New Haven

Hor C, Thaiprasert N (2019) Analysis of international tourism demand for Cambodia. In: Huynh VN, Kreinovich V, Sriboonchitta S, Suriya K (eds). Econometrics of Risk. Studies in Computation Intelligence, vol 538. Springer, Cham

Jones C, Munday M (2010) Tourism satellite accounts for regions? A review of development issues and an alternative. Economic Systems Research 22(4): 341-358 doi:https://doi.org/10.1080/09535314.2010.526594

Kaynak E, Kara A (2012) Assessing tourism market potential in a dynamic emerging economy: Theoretical and empirical insights from Cambodia. Asia Pacific Journal of Marketing and Logistics 24(2):199-221

Khanal B, Gan C, Becken S (2014) Tourism inter-industry linkages in the Lao PDR economy: An input-output analysis. Tourism Economics 20(1): 171-194 doi:https://doi.org/10.5367/te.2013.0255

Kim H, Kim B (2015) Economic impacts of the hotel industry: An input-output analysis. Tourism Review 70(2):132-149

Kobayashi S, Tanji H, Saito K, Huang W, Tada M (2009) Industrial structure of Cambodia and the role of agriculture and fishery in its development. Japan Agricultural Research Quarterly, 43(4), 309-316. https://doi.org/10.6090/jarq.43.309

Kronenberg K, Fuchs M, Lexhagen M (2018) A multi-period perspective on tourism's economic contribution - a regional input-output analysis for Sweden. Tourism Review 73(1):94-110

Kweka J, Morrissey O, Blake A (2003) The economic potential of tourism in Tanzania. Journal of International Development 15(3):335-351

Lejarraja I, Walkenhorst P (2007) Diversification by deepening linkages with Tourism. https://www.semanticscholar.org/paper/Diversification-by-Deepening-Linkages-withTourism-Lejarraja/63bd959d3fbb970d127be280282c5d287a1cc6fa, accessed 14 Feb 2020

Madsen B, Zhang J (2010) Towards a new framework for accounting and modeling the regional and local impacts of tourism. Economic Systems Research 22(4): 313-340

Mazumder M, Ahmed E, Murad M, Alamin A (2011) Identifying economically potential inbound markets for the Malaysian tourism industry. Journal of Vacation Marketing, 17(1):31-49. doi:https://doi.org/10.1177/1356766710391133

Meng X, Siriwardana M, Pham T (2013) A CGE assessment of Singapore's tourism policies. Tourism Management 34:25-36 
Miller R, Blair P (2009) Input-output analysis: foundations and extensions. Cambridge University press

MOT (2012) Tourism Development Strategic Plan 2012-2020. Ministry of Tourism 53(9):153

MOT (2019) Tourism statistics report. Ministry of Tourism, Phnom Penh, Cambodia

Muchapondwa E, Stage J (2013) The economic impacts of tourism in Botswana, Namibia, and South Africa: Is poverty subsiding? Natural Resources Forum 37(2):80-89

Munjal P (2013) Measuring the economic impact of the tourism industry in India using the Tourism Satellite Account and input-output analysis. Tourism Economics 19(6):13451359

Oosterhaven J, Fan T (2006) Impact of international tourism on the Chinese economy. International Journal of Tourism Research 8(5):347-354

Otchia C (2013) How could Industrial Structure Guide the Choice of Development Strategy? A Field of Influence Analysis for the Democratic Republic of Congo. International Journal of Economic Policy Studies 8(1):89-112

Pambudi D, McCaughey N, Smyth R (2009) Computable general equilibrium estimates of the impact of the Bali bombing on the Indonesian economy. Tourism Management 30(2):232-239.

Pratt S (2011) Economic linkages and impacts across the talc. Annals of Tourism Research 38(2):630-650

Pratt S (2015) The economic impact of tourism in SIDS. Annals of Tourism Research 52:148-160

Pratt S, Suntikul W, Dorji U (2018) Economic sustainability? Examining the linkages and leakages between agriculture and hotels in Bhutan. International Journal of Tourism Research 20(5):626-636

Rasmussen P (1956) Studies in inter-sectorial relations, North-Holland

ROG (2018) Rectangular strategy for growth, employment, equity, and efficiency: building the foundation toward realizing the Cambodia Vision 2050 Phase IV. Phnom Penh, Cambodia

Salinger L, Hach S, Samnang C, Seiha N (2005) Measuring Competitiveness and Labor Productivity in Cambodia's Garment Industry. USAID

Schultz S (1977) Approaches to identifying key sectors empirically utilizing input-output analysis, The Journal of development studies 14(1):77-96

Slob B, Wilde J (2006) Tourism and sustainability in Brazil: The tourism value chain in Porto de Galinhas, northeast Brazil. https://www.eldis.org/document/A40745. Posted Jan 2006

Smeral E (2015) Measuring the economic impact of tourism: the case of lower and upper Austria. Tourism Review 70(4):289-297

Sonis M, Hewings G, Sulistyowati S (1997) Block structural path analysis: applications to structural changes in the Indonesian economy. Economic Systems Research 9(3):265280

Teigeiro L, Diaz B (2014) Estimation of multipliers for the activity of hotels and restaurants. Tourism Management 40:27-34

Temurshoev U (2010) Identifying optimal sector groupings with the hypothetical extraction 
method. Journal of Regional Science 50(4):872-890

Tohmo T (2018) The economic impact of tourism in Central Finland: a regional input-output study. Tourism Review 73(4):521-547

UNWTO (2018) Tourism and Sustainable Development Goals - Good Practices in the Americas. World Tourism Organization

Vora-Sittha P (2016) Economic impact of tourism accommodation: Thailand. Asian Social Science 12(7):222-230

WTTC (2019) World travel and tourism economic impact 2019. https://www.wttc.org//media/files/reports/economic-impact-research/regions-2019/world2019.pdf. Accessed 14 Jan 2020

Yamagata T (2006) The garment industry in Cambodia : Its role in poverty reduction through export-oriented development. Discussion Paper No.62, Institute of Developing Economies

Yousif M, Bakr A (2019) Tourism development effect on Saudi economic diversification. Journal of Gulf Economics 1(1):1-20 https://cdn-cms.f-static.net/uploads/827666/ normal_5c0d793a9aa18.pdf. Accessed 14 Jan 2020

Zha J, Shao Y, Li Z (2019) Linkage analysis of tourism-related sectors in China: An assessment based on network analysis technique. International Journal of Tourism Research 21(4):531-543 


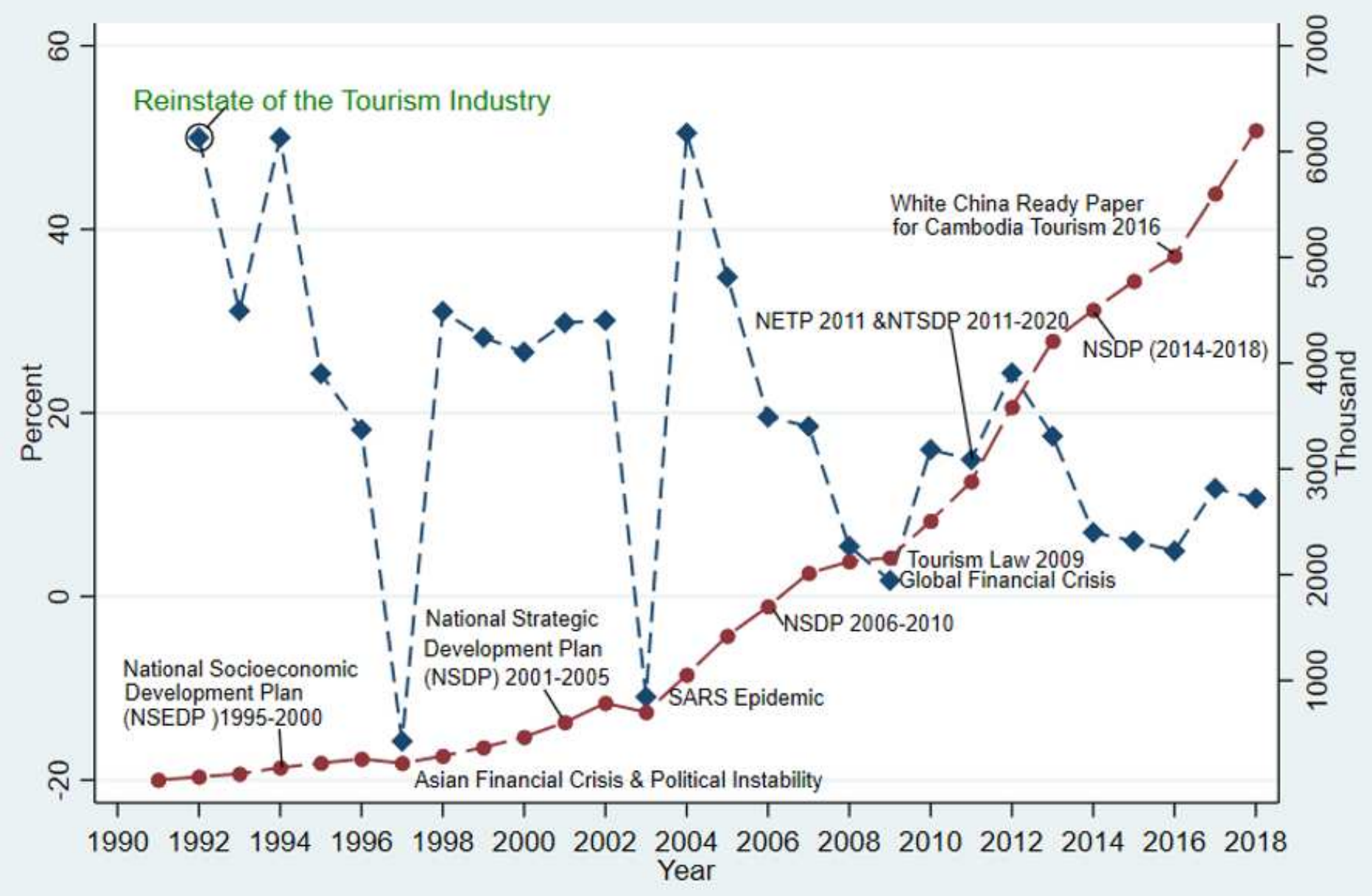

Figure 1

International Tourism Development in Cambodia, 1991-2018. Note: National ecotourism development policy (NETP), National tourism strategic development plan (NTSDP) Source: Author's elaboration based on many sources 


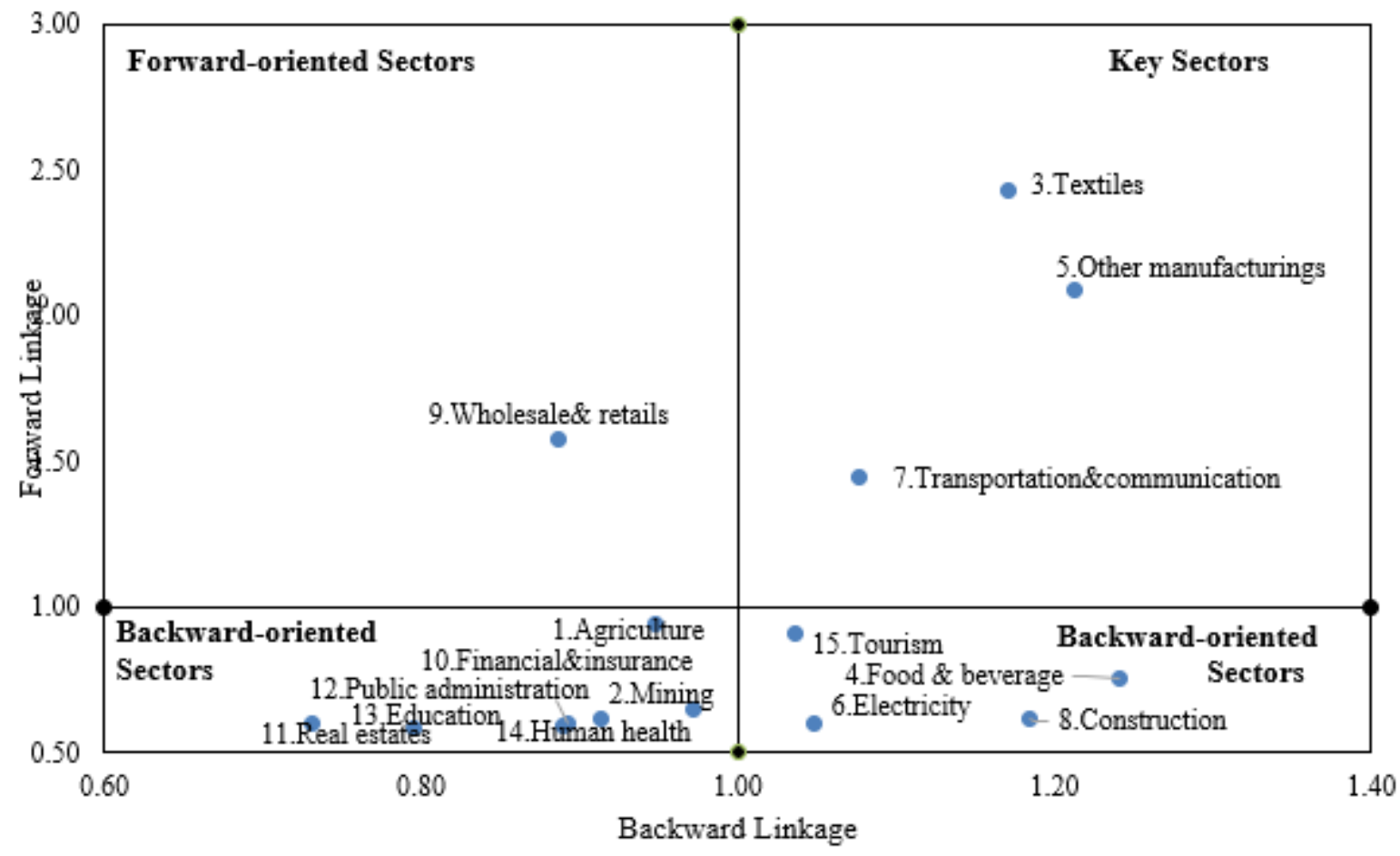

Source: Author's calculation

Figure 2

Key Sectors of Cambodia in 2005

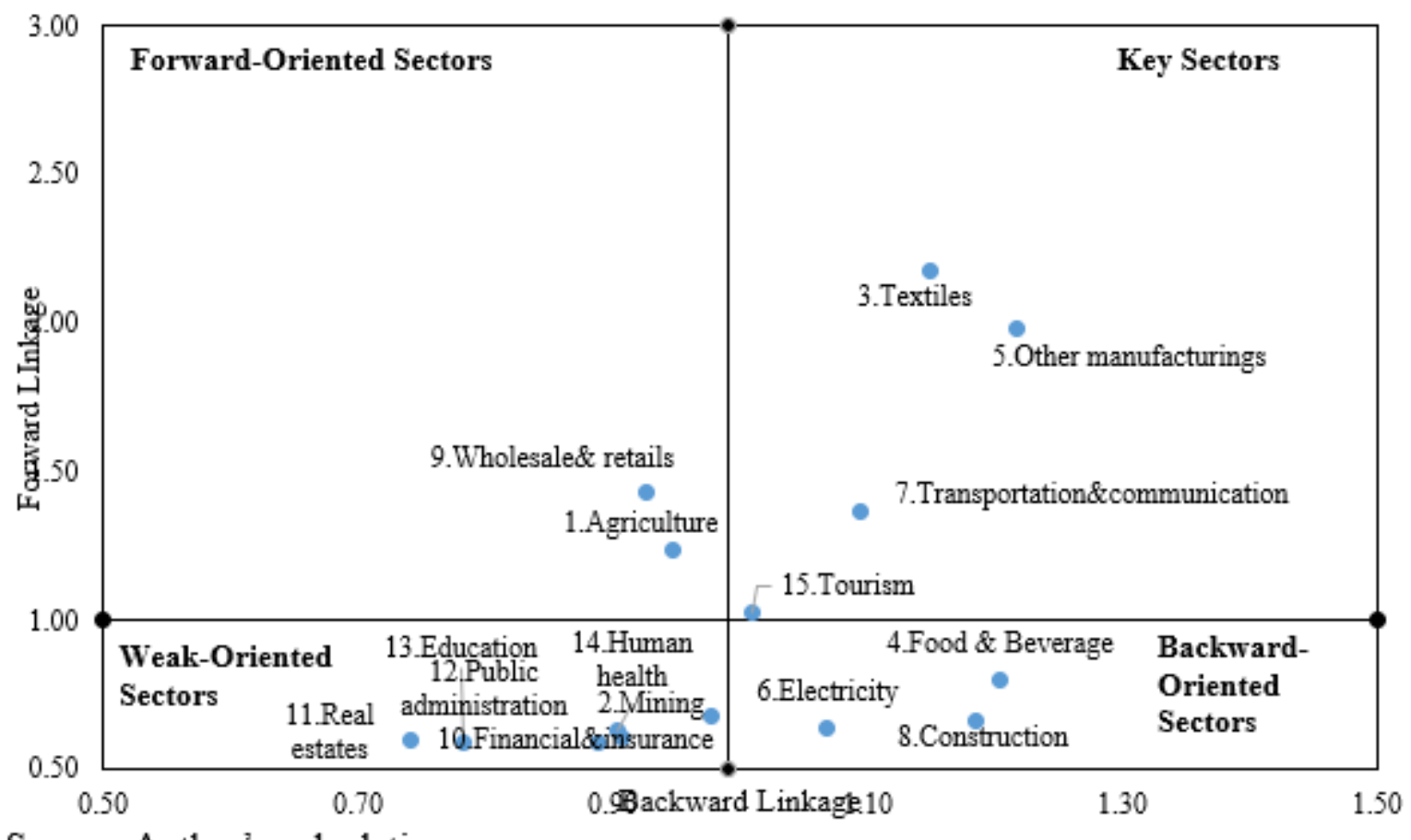

Source: Author's calculation

Figure 3

Key Sectors in 2010 


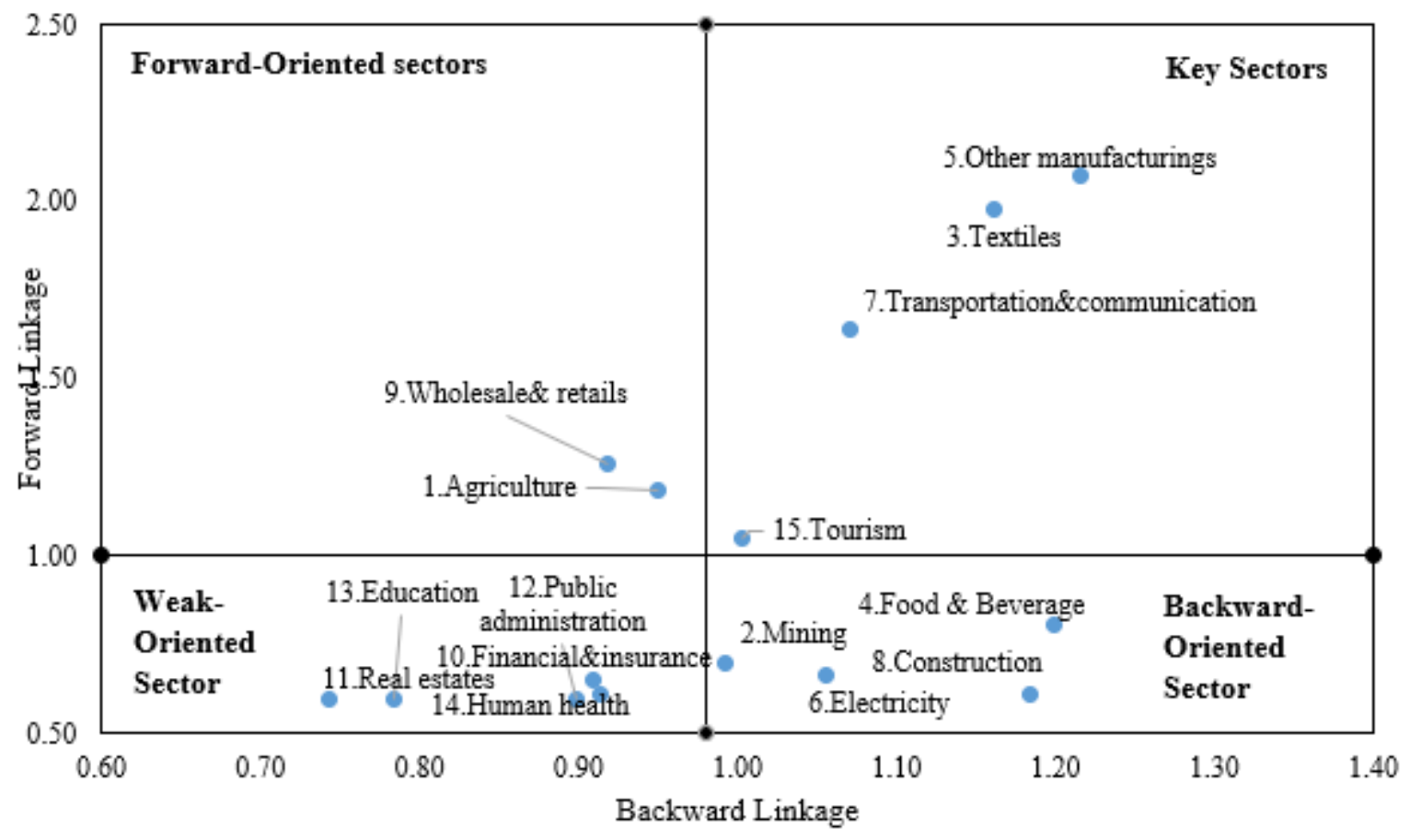

Source: Author's calculation

Figure 4

Key Sectors of Cambodia in 2015

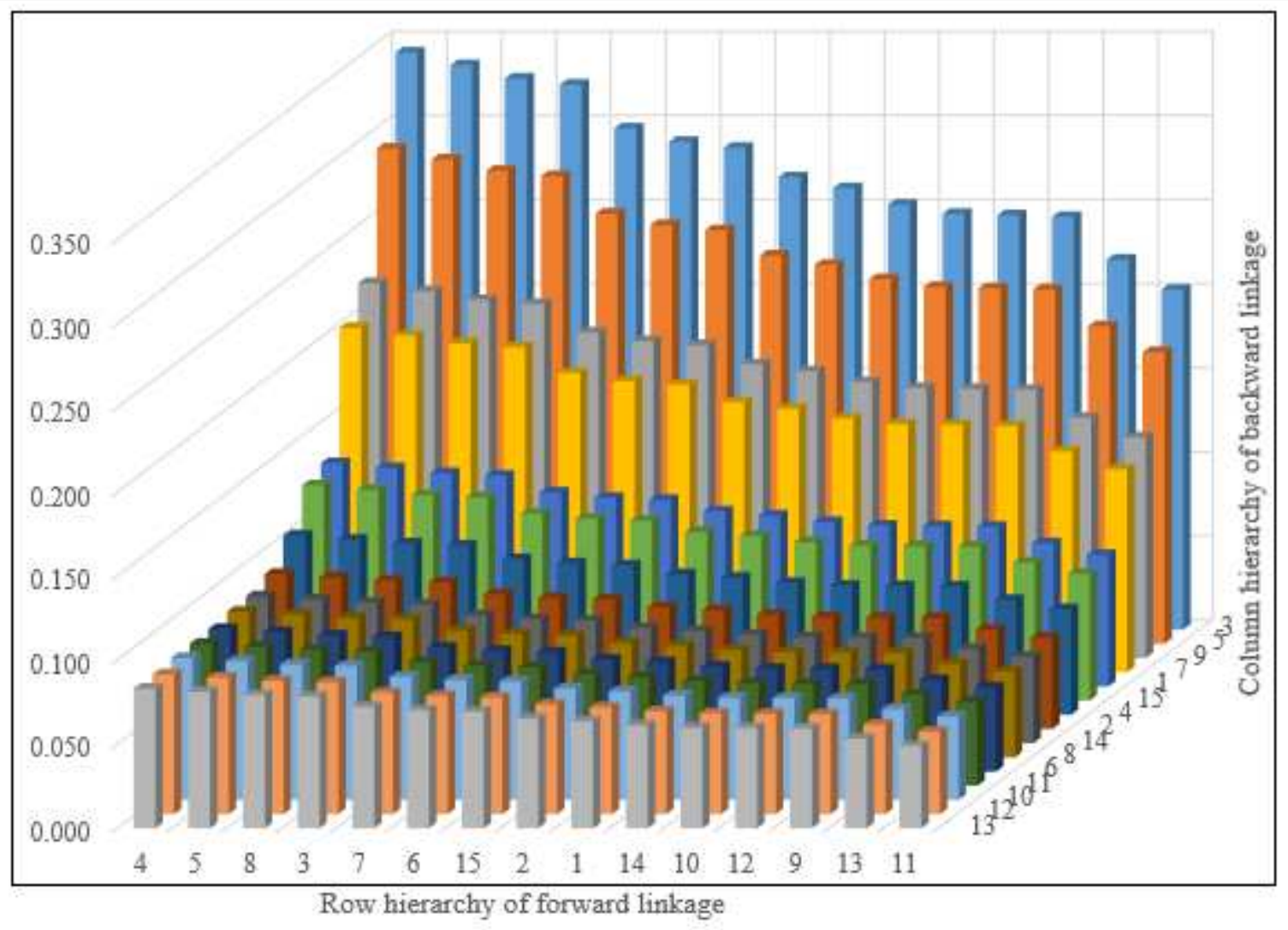

Source: Author's illustration 
Figure 5

Economic Landscape of Cambodian Economy in 2005

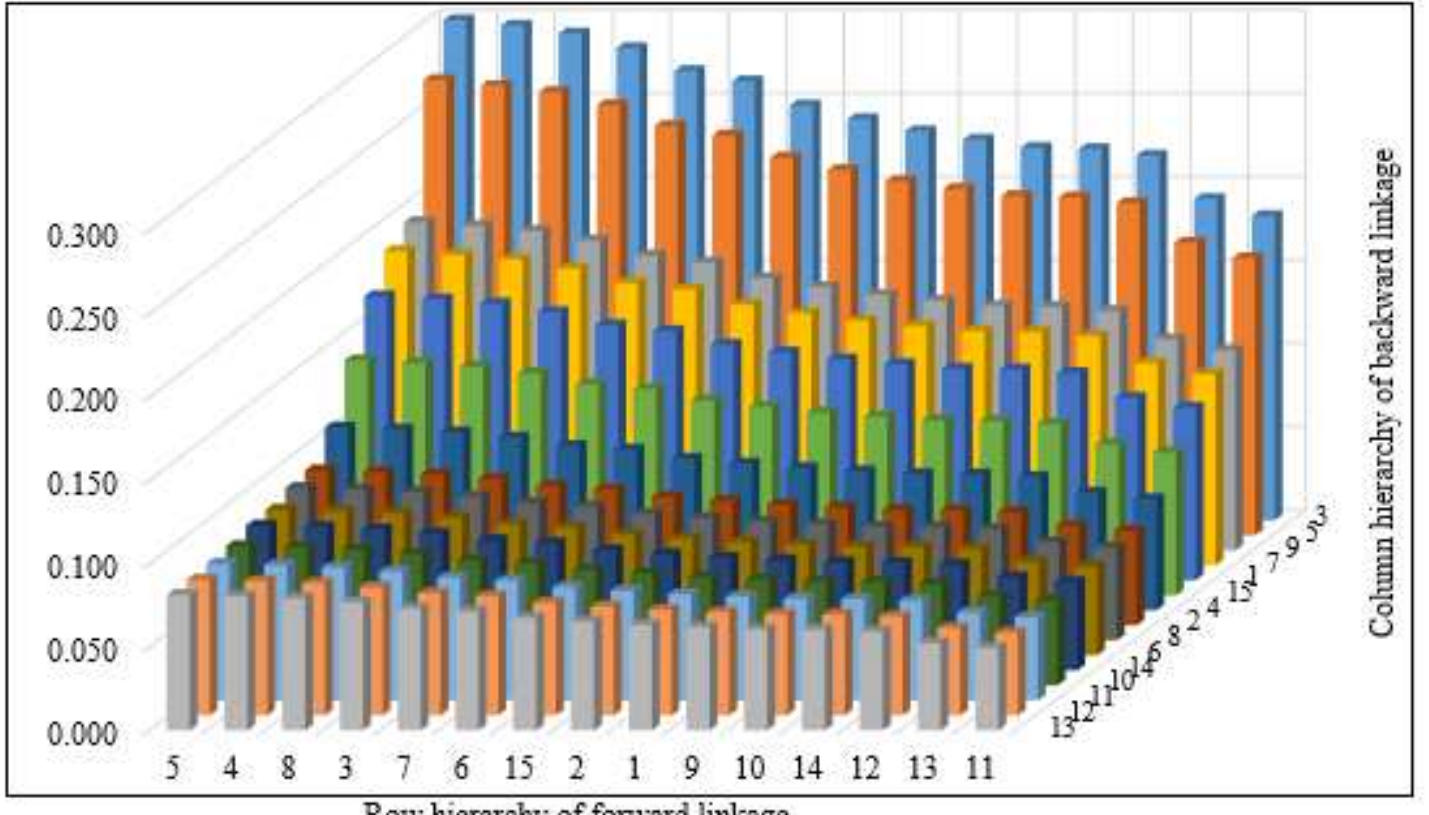

Source: Author's illustration

Figure 6

Economic Landscape of Cambodian Economy in 2010

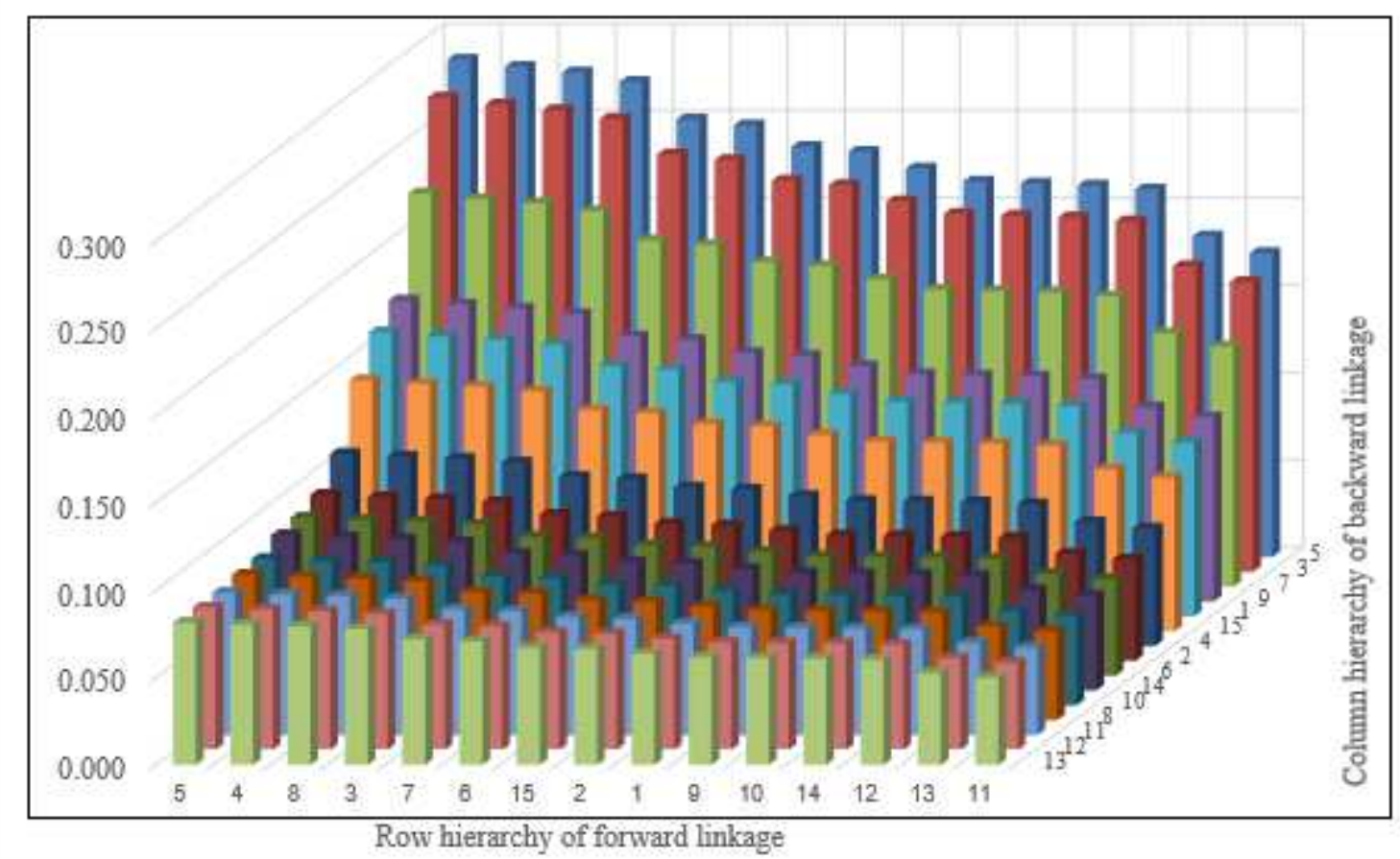

Source: Author's illustration 
Figure 7

Economic Landscape of Cambodian Economy in 2015

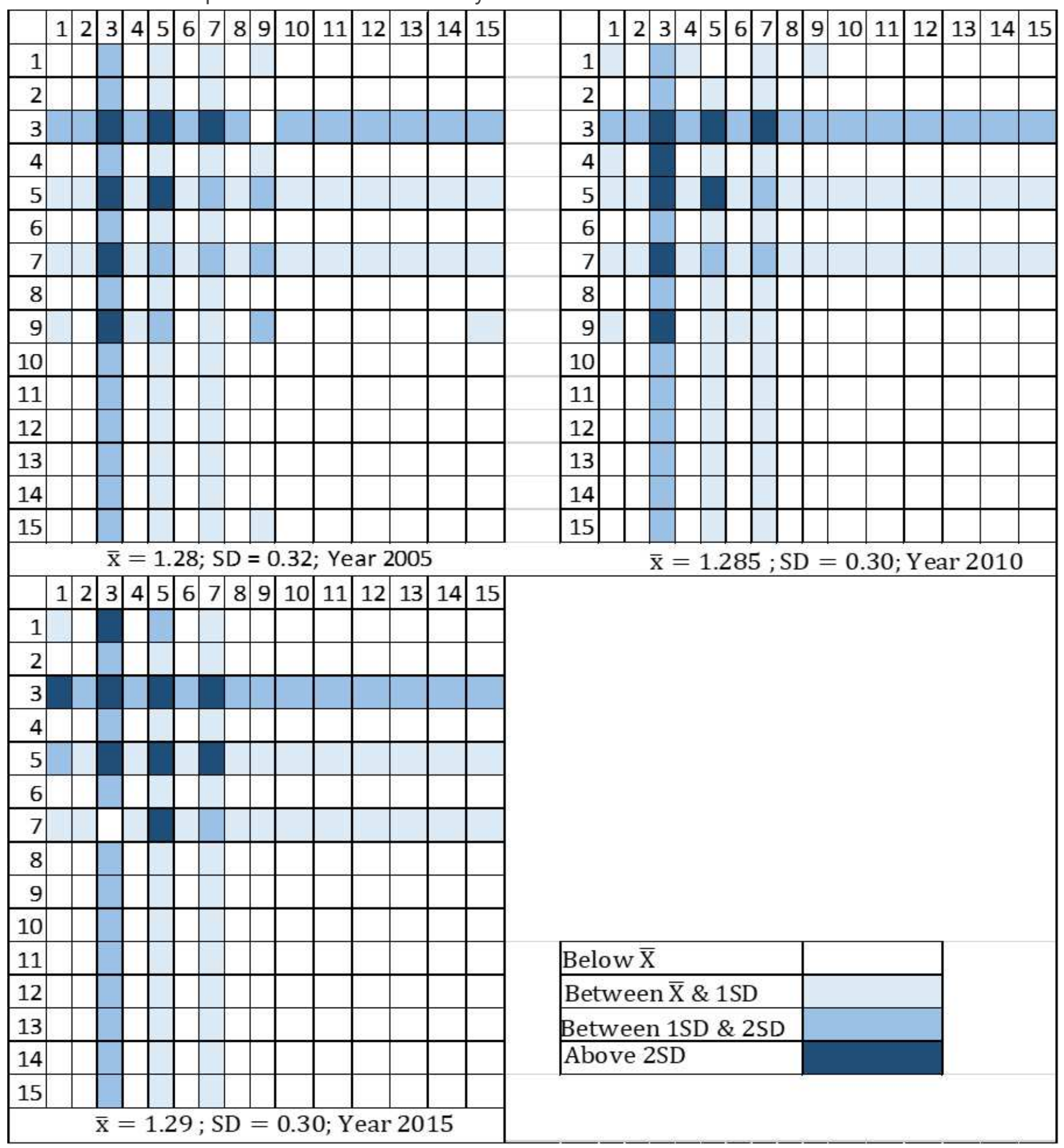

Figure 8

Fields of Influence in 2005, 2010, and 2015 for Cambodia. Source: Author's calculation 